UNIVERSIDADE DE SÃO PAULO

FACULDADE DE FILOSOFIA, CIÊNCIA E LETRAS DE RIBEIRÃO PRETO

PROGRAMA DE PÓS-GRADUAÇÃO EM EDUCAÇÃO

\title{
EDUCAÇÃO E EXPERIÊNCIA RELIGIOSA EM WILLIAM JAMES \\ Contribuições à pedagogia contemporânea
}

Mario Sérgio Coutinho de Matos

Bolsista: CAPES/DS

Ribeirão Preto - 2017 


\section{EDUCAÇÃO E EXPERIÊNCIA RELIGIOSA EM WILLIAM JAMES}

Contribuições à pedagogia contemporânea

Dissertação de Mestrado apresentada ao Programa de Pós-graduação em Educação da Faculdade de Filosofia, Ciências e Letras de Ribeirão Preto da Universidade de São Paulo para obtenção do título de Mestre em Ciências: Educação.

Linha de pesquisa: Fundamentos Filosóficos, Científicos e Culturais da Educação.

Orientador: Prof. Dr. Marcus Vinicius da Cunha. 


\begin{abstract}
AUTORIZO A REPRODUÇÃO E DIVULGAÇÃO TOTAL OU PARCIAL DESTE TRABALHO, POR QUALQUER MEIO CONVENCIONAL OU ELETRÔNICO, PARA FINS DE ESTUdO E PESQUISA, DESDE QUE SEJA CITATA A FONTE.
\end{abstract}

FICHA CATALOGRÁFICA

MATOS, Mario Sérgio Coutinho de.

Educação e experiência religiosa em William James: contribuição à pedagogia contemporânea / Mario Sérgio Coutinho de Matos; orientador Marcus Vinicius da Cunha, Ribeirão Preto, 2017.

Dissertação de Mestrado apresentada à Faculdade de Filosofia, Ciências e Letras de Ribeirão Preto/USP - Programa de Pós-Graduação em Educação.

1. William James. 2. Educação. 3. Experiência religiosa. 4. Pedagogia Contemporânea. 
Nome: MATOS, Mario Sérgio Coutinho de

Educação e experiência religiosa em William James: contribuições à pedagogia contemporânea

Dissertação de Mestrado apresentada ao Programa de Pós-graduação em Educação da Faculdade de Filosofia, Ciências e Letras de Ribeirão Preto da Universidade de São Paulo para obtenção do título de Mestre em Ciências: Educação.

Aprovado em:

Prof. Dr. Antônio dos Santos Andrade

Julgamento:

Profa. Dra. Erika Natacha Fernandes de Andrade Julgamento:

Pro. Dr. Divino José da Silva

Julgamento: 
Este trabalho eu dedico à minha avó, para quem eu nunca mais vou voltar de Ribeirão Preto. 


\section{AGRADECIMENTOS}

Quando ingressei no Programa de Pós-graduação, tudo era uma grande novidade. Lembro-me da primeira aula que tive com o professor Elmir de Almeida, e a primeira impressão que tive pode ser definida pela palavra acolhimento. Senti-me pertencente àquele espaço novo que surgia diante de mim. Meus mais sinceros agradecimentos ao professor Elmir por ter proporcionado essa experiência.

Experiências são o elemento principal do nosso processo de aprendizagem e amadurecimento. Aprendemos por estarmos numa etapa de formação acadêmica que nos coloca em uma situação de encontro com novos conhecimentos, com novos colegas de diferentes formações e com novas possibilidades de pensar o campo da educação. Amadurecemos porque é uma etapa da própria vida, e não um espaço alheio ao nosso mundo. E passar por isso tudo me faz ser grato a pessoas que não me acompanharam nesse processo, mas que estiveram em meu coração; portanto, meus sinceros agradecimentos às tias Maria Clara e Rita de Cássia, e minha avó, Verônica Aparecida.

Estes últimos anos têm sido de muita união com duas pessoas que são parte daquilo que venho me tornando a cada dia, que são muito importantes em minha vida, pessoas que admiro, respeito e amo. Agradeço, então, às duas mulheres que sempre estiveram comigo, mesmo quando eu não estava junto delas: minha mãe, Bernadete, e minha irmã, Bruna.

Agradeço a todos meus familiares que estiveram próximos de minhas idas e vindas, entre Congonhal e Ribeirão Preto. São pessoas que formam minha família e sou feliz por tê-las ao meu lado. Oferto meus sinceros agradecimentos aos meus amigos de Congonhal e de Juiz de Fora por sempre me apoiarem, e também às amizades tão importantes que fiz em Ribeirão Preto. Vocês moram no meu coração. Sou grato também à Taynara por acreditar em mim.

Agradeço à orientação, dedicação e incentivo do professor Marcus Vinicius: foi um aprendizado que não posso traduzir em palavras. Agradeço aos demais colegas integrantes do Grupo de Pesquisa Retórica e Argumentação na Pedagogia, cujas discussões foram solo fértil para as reflexões sobre este trabalho, e por isso muito obrigado. Sou grato também ao Prof. Dr. Antônio dos Santos de Andrade e à Profa. Dra. Erika Natacha Fernandes de Andrade, membros de minha banca de qualificação, pelas preciosas sugestões que deram a este trabalho. 
Obrigado a todos os professores do Programa de Pós-graduação em Educação pela contribuição em minha formação como educador. Agradeço também à CAPES pelo suporte financeiro sem o qual a pesquisa seria inviável. 


\section{RESUMO}

MATOS, Mario Sérgio Coutinho. Educação e experiência religiosa: contribuições à pedagogia contemporânea. Dissertação. Faculdade de Filosofia, Ciências e Letras de Ribeirão Preto, Programa de Pós-Graduação em Educação, Universidade de São Paulo, Ribeirão Preto, 2017.

Este trabalho analisa as proposições educacionais e o conceito de experiência religiosa elaborados por William James (1842-1910), um dos fundadores da corrente filosófica denominada Pragmatismo e responsável por inaugurar o campo da ciência psicológica nos Estados Unidos da América. Considerando que as pesquisas educacionais brasileiras pouco têm se dedicado às ideias jamesianas, o trabalho busca explicitar as teses de James sobre educação por intermédio da análise de suas concepções acerca da religiosidade. São examinados os conteúdos de Talks to teachers on psychology, obra de 1899 em que o autor discute a prática docente e a formação de estudantes, e também os conteúdos de As variedades da experiência religiosa, livro de 1902 em que o autor analisa o fenômeno da religiosidade. O propósito dessas análises é explicitar a noção jamesiana de ensino como arte por intermédio de suas ideias acerca da experiência religiosa. Ao realizar essa meta, este trabalho visa oferecer contribuições para discutir as tendências dominantes da educação na atualidade, caracterizadas como voltadas à mercantilização do ensino.

Palavras-chave: William James; Educação; Experiência Religiosa; Pedagogia Contemporânea. 


\begin{abstract}
Matos, Mario Sérgio Coutinho. Education and religious experience: contributions to contemporary pedagogy. Dissertation. Faculty of Philosophy, Sciences and Letters of Ribeirão Preto, Graduating Program in Education, University of São Paulo, Ribeirão Preto, 2017.
\end{abstract}

This work analyzes the educational propositions and the concept of religious experience elaborated by William James (1842-1910), one of the founders of the philosophical current denominated Pragmatism and responsible for inaugurating the field of psychological science in the United States of America. Considering that the Brazilian educational researches are little dedicated to the ideas of James, the work seeks to make explicit the theses of James on education through the analysis of his conceptions about religiosity. It examines the contents of Talks to teachers on psychology, 1899, in which the author discusses the teaching practice and the formation of students, as well as the contents of The varieties of religious experience, 1902, book in which the author analyzes the phenomenon of Religiosity. The purpose of these analyzes is to make explicit the Jameson notion of teaching as art through his ideas about religious experience. In accomplishing this goal, the work aims to offer contributions to discuss the dominant tendencies of education in the present time, characterized as directed to the commodification of education.

Keywords: William James; Education; Religious Experience; Contemporary Pedagogy. 


\section{SUMÁRIO}

INTRODUÇÃO - p. 12

I - CONVERSANDO COM PROFESSORES E ESTUDANTES - p. 21

1. Conversando com professores - p. 22

O fluxo da consciência - p. 23

Comportamentos, instintos e hábitos - p. 26

Conceitos úteis aos professores - p. 29

2. Conversando com estudantes - p. 32

A função das emoções - p. 32

$O$ controle dos sentimentos - p. 35

O reconhecimento do outro - p. 37

A religiosidade e o significado da vida - p. 49

II - O VALOR DA EXPERIÊNCIA RELIGIOSA - p. 42

1. As diretrizes da investigação - p. 44

O sentimento religioso - p. 46

$O$ sentimento de realidade - p. 47

2. Os componentes da experiência religiosa - p. 49

$O$ ambiente e o temperamento individual - p. 50

A conduta e a unificação de sentimentos - p. 52

A experiência de conversão - p. 54

3. A experiência religiosa no âmbito da cultura - p. 56

A santidade - p. 56

Uma passagem pela história - p. 58

Os estados místicos de consciência - p. 60

4. As contribuições da investigação - p. 62 


\section{III - A ARTE JAMESIANA DE ENSINAR - p. 65}

1. Uma reflexão sobre a educação contemporânea - p. 65

2. Religiosidade e educação: fenômenos complexos e plurais - p. 70

3. A formação de novos hábitos: educar para a diversidade - p. 71

4. Adaptação e transformação: abertura para o novo - p. 74

5. Comunicação: território do inefável e da expressão artística - p. 77

6. Educação como arte - p. 79

\section{CONSIDERAÇÕES FINAIS - p. 83}

REFERÊNCIAS - p. 87 


\section{INTRODUÇÃO}

Parafraseando William James (1842-1910), filósofo norte-americano que constitui o objeto de estudo deste trabalho, podemos dizer que quem se preocupa em definir a essência da educação é, na verdade, quem menos compreende a complexidade da educação. Mesmo os pesquisadores que investigam elementos bem definidos e localizados reconhecem que suas investigações envolvem inúmeros desdobramentos, o que os motiva a posicionar suas análises e conclusões no interior de debates mais amplos. Todo tema de pesquisa é baseado em escolhas, pois não é possível abranger todas as problematizações pertinentes ao campo examinado, cabendo ao pesquisador escolher o caminho que lhe pareça mais frutífero para alcançar os seus propósitos, sempre observando o necessário rigor metodológico.

Quando um estudo se dedica a promover a integração de conhecimentos e interpretações provenientes de diferentes áreas de estudo, é preciso assumir o perfil híbrido e complexo da educação, como faz James (1899, p. v), cujo pensamento se exprime numa passagem que retrata bem as suas disposições pluralistas: "Os fatos e os valores da vida necessitam de vários agentes cognitivos para compreendê-los. (...) Não existe ponto de vista absolutamente universal". Com isso, o filósofo quer dizer que a "verdade é muito grande para qualquer mente isolada (...) conhecê-la por completo". E conclui: "Percepções privadas e incomunicáveis sempre prevalecem, e o pior disso é que aqueles que as buscam a partir do exterior nunca sabem onde encontrá-las".

O presente trabalho enquadra-se nesse registro, tendo por objetivo analisar as contribuições de William James para a educação, de modo geral, e particularmente para a discussão de temas pertencentes ao controvertido cenário pedagógico contemporâneo. A obra de James presta-se a um exercício desta natureza porque reflete o caráter pluralista da interseção entre a ciência e a educação, abrangendo conceitos da psicologia e da filosofia, sendo permeada por problemas concernentes à ética, à moral e à metafísica, mediante o uso de métodos e conceitos próprios, situando-se no alvorecer das tendências da filosofia vigente na atualidade. Ao fazer essa opção de pesquisa, reconhecemos o desafio de nos depararmos não somente com as possibilidades abertas pela filosofia jamesiana, mas também com os limites de suas reflexões.

\footnotetext{
${ }^{1}$ Estes e os demais trechos transcritos de obras não publicadas em língua portuguesa foram traduzidos pelo autor deste trabalho. Em todo este trabalho, os grifos situados no interior de trechos aspados são dos originais transcritos.
} 
Um dos traços da obra de James é a interdisciplinaridade, o que a situa no interior das tensões que são próprias desse tipo de abordagem. Seus trabalhos refletem a riqueza de suas experiências de vida, a começar por uma educação familiar que, sob a orientação de seu pai, Henry James, agregava fundamentos oriundos de grandes filósofos, como Rousseau, e ensinamentos eivados de intensa espiritualidade (MACHADO, 2011; BJORK, 1988; MURPHY, 1993). James "gastou quinze anos tentando se estabelecer em uma ocupação, mudando da ciência para a pintura, da pintura para a ciência novamente, então para a química, a anatomia, a história natural, e finalmente para a Medicina" (MENAND, 2001, p. 75).

A essa característica peculiar para os padrões de ensino da época, logo após sua breve experiência no meio artístico, quando estudou desenhos e pinturas entre os anos de 1859 e 1860, soma-se uma viagem feita ao Brasil na expedição Thayer, em 1865, juntamente com o naturalista suíço Louis Agassiz, seu professor na Harvard School of Medicine (MACHADO, 2011). ${ }^{2}$ Esses e outros fatos mostram a complexidade e a pluralidade do cenário em que James viria a compor seus escritos. ${ }^{3}$

A trajetória formativa de James é examinada por John Shook (2002, p. 87), que sugere, como ponto de destaque, sua "justificação da fé na experiência religiosa pessoal", o que constitui um "princípio central do protestantismo e do transcendentalismo", fortes influências sofridas por sua filosofia. Shook nota o contraste entre o filósofo e seu irmão, o escritor Henry James, cujas obras exprimem "profunda afeição à cultura europeia", enquanto ele mesmo se sentia atraído pelo "gosto americano pela aventura e pela novidade".

Bjork (1988, p. 12-13) acrescenta que James viveu parte importante de sua vida no continente europeu, onde esteve na adolescência estudando em países como Suíça, Inglaterra e França, experiência que estabeleceu forte "impacto cultural e educacional" sobre ele. Na medida em que "passava de escola para escola, de tutor para tutor - um processo educativo monótono do qual se arrependeria depois - uma constante surge: seu interesse permaneceu fixado sobre a arte e pintura". A dimensão artística permeou o processo educativo de James, repercutindo em seus conceitos mais importantes, como a ideia de fluxo da consciência.

\footnotetext{
${ }^{2}$ Sobre a expedição Thayer, ver Agassiz e Agassiz (2000), Menand (2001) e Machado (2001).

${ }^{3}$ Certos acontecimentos de sua vida pessoal são invocados, nessa mesma direção: uma forte depressão em 1866; problemas emocionais durante a viagem ao Brasil, na qual contraiu varíola e passou por uma crise espiritual; novos episódios depressivos nos anos de 1869, 1870 e 1871, e problemas no coração em 1898 (MACHADO, 2011; BJORK, 1988).
} 
Desde a idade de oito anos, estimulado por seu pai, Henry Sênior, o menino William começou a manter contato com a pintura, fazendo frequentes visitas a galerias de arte, tanto nos Estados Unidos como na França e na Inglaterra, o que desenvolveu nele intenso interesse pelo mundo artístico (BJORK, 1988, p. 8-9). O propósito de seu pai, quando da viagem à Europa, era que os filhos tivessem uma "educação sensória" baseada nos "aprimoramentos artísticos e espirituais da civilização ocidental". A produção do pintor francês Eugène Delacroix forneceu elementos que serviriam de modelo, "tanto na forma como no tema" para "muitos esboços subsequentes" de William James (idem, p. 14).

Apesar dessas influências, James nunca se dedicou a um estudo exclusivo sobre a arte. Quando retornou da Europa, em 1858, optou pela ciência, ingressando na Lawrence Scientific School da Universidade de Harvard, em Cambridge. No final dos anos de 1880 e início da década seguinte, já na Universidade de Cambridge, tornou-se professor e conferencista renomado, pesquisando no recente campo da psicologia, o qual ele mesmo havia ajudado a inaugurar nos Estados Unidos (BJORK, 1988, p. 3637). Na década de 1890, o interesse pela ciência o levou à filosofia, campo em que desenvolveu uma vertente específica da corrente filosófica denominada Pragmatismo.

A fundação do Pragmatismo é atribuída a Charles Sanders Pierce (1839-1914), logo seguido por James. Além deles, outro célebre adepto dessa filosofia foi o também norte-americano John Dewey (1859-1952), que se notabilizou por suas proposições na área da educação. Segundo Menand (2001, p. x-xi), esses três filósofos foram responsáveis por "conduzir o pensamento americano ao mundo moderno", produzindo profundas mudanças no modo de viver e pensar dos habitantes de seu país, com repercussões que chegam à atualidade por meio de conceitos relativos a "educação, liberdade, justiça e tolerância”. É deles a concepção de que as ideias não são dadas, descobertas, mas criadas, produzidas pelas pessoas "para lidar com o mundo em que se encontram", assumindo assim um caráter instrumental.

Murphy (1993, p. 67) explica que o termo pragmatismo, escolhido por James para caracterizar suas proposições filosóficas, tem origem na ideia contida no vocábulo grego pragma, com o significado de ação. O pragmatismo de James possui uma dimensão voltada aos processos comuns, as experiências de vida diária das pessoas, buscando verificar nas condutas assim produzidas os sentidos que compõem ideias e conceitos. O pragmatismo jamesiano ocupa-se com a análise das consequências possíveis de determinadas teorias, conceitos, afirmações, frases do senso comum, em 
busca de evidências. Para James, "se alguém puder definir com precisão os mundos possíveis e todas as vidas possíveis nos quais uma frase é verdadeira, temos, aí, um cômputo completo da credibilidade do que a frase diz". Transcrevendo um trecho da obra Pragmatismo de James, Murphy (idem, p. 68) registra que "toda a função da filosofia deveria ser a de encontrar que diferença definida fará para cada um de nós, em momentos definidos da nossa vida, que esta fórmula-mundo ou aquela fórmula-mundo seja a que efetivamente é verdadeira". ${ }^{4}$

Além de Pragmatism, livro de 1907 resultante de conferências em que o autor procura definir o que entende por pragmatismo, outros trabalhos de sua autoria, igualmente impactantes, foram The principles of psychology, de 1890, obra-prima que o projetou como grande nome da "nova psicologia"; The will to believe, de 1897, que inaugurou a sua fase de estudos filosóficos; e Talks to teachers on psychology, de 1899, fruto de conferências dirigidas a professores, versando sobre temas do campo da psicologia e assuntos de cunho moral e filosófico. Em 1909 foram publicadas as obras The meanining of truth e A pluralistic universe, ambas sobre filosofia; em 1912, dois anos após o falecimento do filósofo, Henry James tomou a iniciativa de publicar Essays in radical empiricism, uma compilação de artigos extraídos das aulas de filosofia ministradas por seu irmão na Universidade de Harvard, no início dos anos 1900.

Posnock (1998, p. 323) destaca a influência de James na cultura americana, afirmando que seu impacto "é sentido na literatura moderna, sociologia, teoria política, psicologia (incluindo a experimental e a behaviorista), filosofia (não apenas o pragmatismo, mas também a fenomenologia) e na teologia”. Isto se explica pelo fato de a filosofia jamesiana ser imbuída de uma atitude contrária a convenções e sistemas definidos. "James está sempre se voltando do estabelecido e definido para aquela 'zona de insegurança nas relações humanas' que nós chamamos de presente".

Os variados interesses intelectuais de James são projetados em seus estudos, que se apresentam sem compromisso rígido com a formalidade científica, indicando, outrossim, a indissociabilidade entre a sua vida particular e as suas reflexões, o que o levou a um modo peculiar de fazer ciência (BJORK, 1988; DEWEY, 1946). A busca por iluminação e por significados para as coisas foi uma atividade que ocupou James durante toda sua vida, resultando em uma forma única e idiossincrática de interpretar e abordar temáticas clássicas da filosofia, focalizando especialmente o combate aos

\footnotetext{
${ }^{4}$ JAMES, William. Pragmatism. Indianapolis: Hackett Publishing Co., 1981.
} 
dualismos tão marcantes no pensamento filosófico, como corpo e mente, monismo e pluralismo, indivíduo e sociedade.

Podeschi $(2002$, p. 58) traça um paralelo entre as conjunturas sociais, políticas e econômicas do início do século XX e as do início do século XXI, e encontra hoje o mesmo desafio observado por James há mais de um século: "como estimular a individualidade criativa diante de forças sociais que nos impelem em direção a padronizações estreitas e objetividade mecânica". O autor avalia que a preocupação de James repercute no âmbito educacional, podendo ser identificada no discurso atual que enfatiza termos como "profissionalização", "especialidade técnica" e "consenso metodológico", os quais constituem "rótulos" que inibem e "ameaçam o pluralismo de ideias e ideais".

Acreditamos que a filosofia de James permanece viva e pode oferecer inúmeras contribuições a quem se disponha a enfrentar os problemas contemporâneos da educação. Seu caráter questionador das convenções e dos paradigmas estabelecidos à custa da experiência individual merece ser retomado, juntamente com a sua atitude reflexiva que valoriza os sentimentos, os anseios, os desejos e os ideais de cada pessoa. É preciso observar, no entanto, que a produção intelectual de James é raramente associada à educação, o que talvez se deva ao fato de outro pragmatista, John Dewey, ter ofuscado a relevância de suas ideias nessa área, praticamente as relegando à marginalidade (BREDO; GARRISON; PODESCHI, 2006, p. xii).

Essa marginalização constitui um paradoxo, uma vez que The principles of psychology, de 1890, é tida como fundadora da psicologia moderna, cujas concepções encontram-se na raiz da educação progressiva deweyana (BREDO; GARRISON; PODESCHI, 2006, p. xii). ${ }^{5} \mathrm{Na}$ virada do século XIX para o XX, havia grande efervescência em torno da psicologia, um terreno ainda incipiente naquela época. Especificamente nos Estados Unidos da América, foi o trabalho de James que impulsionou o interesse dos pesquisadores e contribuiu para estruturar o campo, os recursos, os conceitos e os objetos da investigação psicológica. O conjunto da obra jamesiana, que sempre carrega traços de Principles, teve amplo alcance e influenciou inúmeros filósofos, como John Dewey, George Herbert Mead e Charles Cooley, e

\footnotetext{
${ }^{5}$ Daqui por diante, mencionaremos as obras de James utilizando tanto os seus títulos completos quanto formas abreviadas - por exemplo: The principles of psychology (Principles); Talks to teachers on psychology (Talks to teachers ou Talks); As variedades da experiência religiosa (Variedades). Quando não houver tradução da obra para a língua portuguesa, utilizaremos o título original em inglês.
} 
também psicólogos, como James Mark Baldwin e John B. Watson, além de diversos sociólogos e teólogos (POSNOCK, 1998, p. 322).

Um dos grandes desafios de James ao publicar The principles of psychology foi o de apresentar a psicologia como um campo científico digno de respeito, visando incentivar pesquisas que viessem dar robustez à nova área de investigação (MENAND, 2001, p. 370). Contudo, James (1899, p. 156) notou haver uma crescente busca por recursos financeiros na pesquisa, levando a apropriações perversas da psicologia, com forte cunho mercadológico, às quais se referiu como "mistificações industriosas por parte dos editores e das companhias editoriais". A partir de então, ele perdeu a motivação inicial, passando a se dedicar à filosofia, porém sempre em constante diálogo com os conceitos oriundos de suas proposições psicológicas, como é o caso, por exemplo, da ideia de "fluxo da consciência" (VAN WESEP, 1966).

Obras como $A$ vontade de crer, de 1896, e As variedades da experiência religiosa, de 1902, integram o conjunto de produções elaboradas por James após o seu afastamento do campo da psicologia e o seu consequente ingresso na filosofia. Somamse a elas uma série de artigos publicados avulsamente e o lançamento de Pragmatismo, em 1907, e A pluralistic universe, em 1909, sendo esta a sua derradeira publicação em vida. Mesmo quando já se ocupava estritamente com a filosofia, James não abandonou certos recursos metodológicos e conceitos forjados no âmbito de suas reflexões psicológicas. Alguns desses elementos foram decisivos em suas obras filosóficas, como postula Van Wesep (1966, p. 153) ao afirmar que "James foi o iniciador de uma nova ciência da psicologia, antes de se dedicar a dar nova forma a uma filosofia que tinha como fundamento essa mesma psicologia”.

Merece destaque uma obra que, mesmo sendo posterior ao afastamento de James da psicologia, faz uma retomada de temas presentes em Principles. Trata-se de Talks to teachers on psychology, que tem por subtítulo "and to students on some life's ideals", publicada em 1899. O que pode justificar o retorno do autor à psicologia é que a obra foi editada com base em uma série de conferências realizadas por ele a partir de 1892 , cumprindo o objetivo de esclarecer a professores e estudantes o papel assumido pela psicologia após a publicação de Principles, trabalho que vinha obtendo grande repercussão na época. Sendo Principles um livro extenso, havia uma demanda por esclarecimentos de cunho prático acerca dos conceitos nele veiculados, além de grande expectativa quanto às contribuições da psicologia para a educação. Por isso, a Universidade de Harvard convidou James, que era professor da instituição, a proferir 
conferências para esclarecer as funções da nova ciência, como também as possibilidades de sua articulação com as práticas de ensino (JAMES, 1899, p. iii).

Segundo Pajares (2003, p. 51), Harvard optou em 1891 por contratar profissionais dedicados a estudos educacionais, sendo proposto a eles que proferissem conferências para lidar com temáticas relativas a essa área. Esse processo resultou na criação do Departamento de Educação, em 1906, e de uma Escola de Pós-Graduação, em 1920. Entre os docentes, James foi talvez o primeiro a "extrair avaliações para seu ensino a partir de seus estudantes", incorporando "os frutos de seu trabalho no interior de sua própria prática de ensino". Pajares afirma que James foi "o primeiro psicólogo norte-americano a proferir conferências diretamente sobre questões educacionais".

Ainda que a ideia de se dirigir aos professores não tenha surgido de necessidades ou disposições sentidas por ele, mas pela direção da Universidade, é possível dizer que James se viu envolvido e motivado pela atividade, uma vez que, para elaborar as suas intervenções, procurou conhecer os questionamentos, as dúvidas e as expectativas dos professores. "Eu tenho observado pela experiência - diz ele - que o que o meu auditório menos deseja é tecnicalidade analítica, e o que mais o atrai são as aplicações práticas”. Nessa mesma passagem, logo no início de Talks to teachers on psychology, e tendo em mente essa demanda, James (1899, p. iii) explica que não pretende abordar teorias, conceitos e outras abstrações, mas pensar a psicologia em suas articulações com questões práticas, buscando a maior objetividade possível.

O livro Talks to teachers é dividido em duas partes, sendo a primeira direcionada a professores, compreendendo proposições gerais da psicologia jamesiana em articulação com problemáticas da docência; a segunda versa sobre questões éticas e morais presentes na vida em geral, sendo voltada a estudantes. ${ }^{6}$ Sempre entrelaçadas com temas próprios da função docente, as palestras da primeira parte se desenvolvem em torno da noção de "ensino como arte", enfatizando a criatividade e a sensibilidade que o autor julga necessárias ao exercício da docência. Para elucidar a que se refere, James se limita a algumas ideias gerais - tais como criatividade, tato, percepção concernentes à adoção de certas disposições do professor diante do aprendiz, sem explicitar as referências teóricas que sustentam suas teses.

\footnotetext{
${ }^{6}$ Apenas uma das três conferências que compõem o livro - "The gospel of relaxation" registra o perfil dos estudantes e a etapa da educação a que se dirige: James $(1899$, p. iv) falava para alunas de pós-graduação da Boston Normal School of Gymnastic.
} 
$\mathrm{Na}$ segunda parte são apresentadas algumas noções que podem nos auxiliar a compreender a ideia de ensino como arte. A expressão "riqueza interior", que aparece no segundo capítulo de Talks to students, por exemplo, refere-se aos valores que cada pessoa carrega dentro de si, o que talvez se aplique aos qualificativos que, na visão do autor, são imprescindíveis à prática docente. O mesmo pode ser dito quanto à explicação de que no intercâmbio entre os indivíduos pode haver certa "cegueira" prejudicial ao diálogo em busca de consenso - o que, supostamente, deve ser evitado na relação entre professores e alunos, para que o ensino se constitua como arte. Há também o que o autor qualifica como "inspiração religiosa", responsável por despertar o indivíduo para a "riqueza interior", e que tem mais valor do que "uma grande quantidade de informações técnicas e acuradas que os professores supostamente devem ser aptos a oferecer" (JAMES, 1899, p. 296-297).

Na obra imediatamente posterior a Talks, o livro As variedades da experiência religiosa, publicado em 1902, quando James já se afastara da psicologia, aparece uma expressão - "experiência religiosa" - que, segundo julgamos, também contribui para dimensionar a noção jamesiana de ensino como arte. A expressão remete a um tipo específico de experiência, não necessariamente ligada a uma religião específica, podendo ser definida como o que leva o indivíduo a se sentir em contato com aquilo que considerado "divino" (JAMES, 1995, p. 32). James avalia que os indivíduos que passam por tal experiência apresentam certas características comuns, tornando-se mais propensos a estabelecer contatos mais profundos com os outros e com o meio em que vivem - o que, podemos supor, compõe o arsenal de disposições morais favoráveis à efetivação do ensino como arte.

Para analisar as contribuições de William James à educação, objetivo central desta pesquisa, optamos por investigar o livro Talks to teachers on psychology e também As variedades da experiência religiosa, em consonância com as sugestões expostas nesta seção introdutória. Acreditamos que o exame do discurso veiculado no primeiro livro permitirá entender de que modo James articula as suas concepções psicológicas com temáticas próprias da prática escolar. O estudo do segundo livro, que discorre sobre a formação do indivíduo por meio de uma experiência singular, que James denomina religiosa, poderá esclarecer e ampliar os conceitos presentes no primeiro.

Pretendemos apresentar os resultados de nossa pesquisa em três capítulos. Os dois primeiros abordarão respectivamente Talks e Variedades, visando expor as ideias 
centrais do autor e comentá-las, sempre que possível, à luz de outros referenciais educacionais brasileiros; julgamos adequado dar a esses capítulos uma feição estritamente expositiva, sem aventurar análises de maior envergadura. Caberá ao terceiro capítulo desenvolver a discussão sobre as relações que vemos entre os dois livros, com o intuito de apresentar contribuições para os debates que hoje se desenvolvem na educação. 


\section{I - CONVERSANDO COM PROFESSORES E ESTUDANTES}

Embora as contribuições de John Dewey para a educação sejam sensivelmente mais numerosas, significativas e impactantes do que as reflexões de William James nessa mesma área, alguns pesquisadores estrangeiros têm se mobilizado para examinar o pensamento jamesiano no campo educacional. ${ }^{7}$ No Brasil, Mariana Tavares Ferreira lembrou o centenário da morte de James oferecendo ao público a tradução em língua portuguesa do primeiro capítulo de Talks, em publicação feita pela revista CognitioEstudos (JAMES, 2010).

Nessa edição, Ferreira (2010, p. 191) destaca a noção jamesiana de "continuidade da experiência" para enfatizar a relevância das ideias do filósofo, "tanto por sua originalidade e ousadia como pela beleza na forma de apresentá-las", e termina por sugerir que outros esforços sejam empreendidos para "tornar sua obra mais acessível aos leitores de língua portuguesa". Essa última consideração evidencia o fato de James ser ainda pouco difundido entre nós, especialmente se o compararmos à repercussão das teses deweyanas na área de educação.

A atualidade de Talks pode ser aquilatada ao observarmos que Ferreira, escrevendo um século depois de James, apresenta questionamentos semelhantes aos do filósofo. Em James, identifica-se um desconforto perante o mal-entendido de que a prática de ensino seja uma psicologia aplicada, ideia que leva a muitas frustrações no exercício da docência e torna a ciência psicológica uma ferramenta feita unicamente para moldar comportamentos. Ferreira faz eco a essa preocupação, notando que, ainda hoje, acredita-se que os saberes psicológicos possam fornecer aos educadores um manual ou uma receita de como ensinar.

Foi para lidar com tais problemas que James escreveu Talks. Ao retomá-lo no presente trabalho, esperamos atender ao convite feito por Ferreira (2010, p. 192) para que façamos uma reflexão sobre o ensino atual, "pensando pragmaticamente as relações entre o saber-fazer e o saber-sobre, ou entre Arte e Ciência", imbuídos de um olhar crítico à "tecnificação" e à "psicologização" que ainda se fazem presentes nos meios educacionais, tendendo à hegemonia. James não apenas sugere meios para tornar os conhecimentos da psicologia úteis ao ensino; acima de tudo, ele desenvolve uma

\footnotetext{
7 Ver, por exemplo, Putnam (1998), como também os vários textos reunidos na coletânea editada por Bredo, Garrison e Podeschi (2002), mencionada na introdução do presente trabalho.
} 
reflexão filosófica sobre a educação, e o faz de tal modo que as suas ideias assumem certo caráter de universalidade, oferecendo contribuições para pensarmos também o contexto educacional brasileiro.

\section{Conversando com professores}

Condizente com o que Ferreira (2010, p. 191) denomina "espírito jamesiano" uma tendência a fugir de abstrações sem vínculo com a realidade ou a experiência -, a primeira parte de Talks to teachers on psychology é um exercício de interação e debate com professores acerca de assuntos que os mobilizavam em seu ofício. O título do livro poderia ser traduzido como Discurso aos professores, ou mesmo Conferências, seguindo a tradição expositiva típica das lectures praticadas nas universidades norteamericanas, mas Ferreira prefere Conversas com professores, nome que parece mais próximo do modo como James se posicionava no mundo.

Talks visa estabelecer uma articulação entre dois elementos: a psicologia, ciência que tornou James uma celebridade no meio acadêmico norte-americano no fím do século XIX, e o ensino, mais precisamente as questões práticas vivenciadas em sala de aula. James tinha em mente que a psicologia não era composta por saberes oriundos da prática docente e que o objetivo das investigações psicológicas não era voltado ao aperfeiçoamento das relações escolares. Assim, o primeiro capítulo do livro transcrição da primeira conferência, denominada "A psicologia e a arte de ensinar" ocupa-se em distinguir entre o campo da psicologia como ciência e a esfera do ensino, caracterizado como arte. ${ }^{8}$

Os professores estão equivocados, afirma James (1899, p. 7), se imaginam que "a psicologia, sendo a ciência das leis da mente, é alguma coisa da qual eles podem deduzir programas, esquemas e métodos de ensino para uso imediato na sala de aula”. É assim porque a "Psicologia é uma ciência, e ensinar é uma arte". Essa distinção categórica percorre todo o livro, desde a explicação introdutória em que James (1899, p. v) configura Talks como um estudo que traz um "mínimo do que é considerado 'científico' em psicologia", pretendendo tornar-se "prático e popular ao extremo". Sua meta, portanto, é veicular uma síntese do que a psicologia pode oferecer à educação, colocando em primeiro plano as problemáticas do ensino como arte.

\footnotetext{
${ }^{8}$ Adotamos aqui o título dado ao capítulo por Ferreira, na publicação já mencionada.
} 
A concepção de ensino como arte ocupa lugar central nas reflexões jamesianas acerca do docente, tornando-se clara na ressalva que o autor introduz em sua conversa com os professores:

Nenhum meio de mensuração elementar, capaz de ser manipulado em um laboratório, pode projetar luz sobre a eficiência atual do indivíduo, pois o seu elemento vital, sua energia moral e emocional e sua obstinação, não pode ser mensurado por nenhum experimento isolado, sendo conhecido apenas pelo resultado total a longo prazo (JAMES, 1899, p. 135).

James (1899, p. 7) assinala que o núcleo científico da psicologia reside em suas “concepções fundamentais", as quais, "salvo a teoria da evolução, estão longe de serem novas"; de modo geral, "não há nada além da velha psicologia dos tempos de Locke, com adição de um pouco de psicologia do cérebro e dos sentidos e da teoria da evolução, além de alguns refinamentos de detalhe introspectivo" - e todos esses conhecimentos não possuem qualquer tipo de ajustamento às necessidades dos professores, constituindo somente abstrações pouco ou nada concernentes à prática docente. É por isso que James prefere ater-se às referidas concepções fundamentais da psicologia, pondo em destaque o caráter funcional da mente, para nortear sua conversa com os docentes.

\section{O fluxo da consciência}

Tomando por base a concepção dualista que permeia a história da filosofia, James discute em Talks a concepção de mente como instância ocupada com a contemplação, tal qual se identifica na tradição clássica herdada de Platão e Aristóteles, que entendem o humano como um ser que é, antes de tudo, racional. A teoria evolucionista de Darwin, porém, permitiu surgir uma nova visão, a do ser prático. James (1899, p. 24-5), então, solicita aos professores que adotem com ele a "concepção biológica (...) e dirijam sua atenção para o fato de que o ser humano (...) é primariamente um ser prático, cuja mente lhe é dada para auxiliar sua adaptação à vida no mundo".

Estudiosos de James o situam entre os filósofos que foram fortemente influenciados pela teoria da evolução de Charles Darwin (BREDO, 2002; HICKMAN, 
2008). Phillips (2002, p. 118) informa que ele foi "um dos primeiros a reconhecer as implicações psicológicas da teoria da evolução" e que o livro Talks to teachers expressa "de forma muito direta" o "núcleo da linha de pensamento evolucionária" de James. Menand (2001, p. 141) defende que o pensamento jamesiano, tanto na psicologia como na filosofia, foi forjado no âmbito de uma tradição iniciada com $A$ origem das espécies, mas esclarece que James não compartilhou da ideia de evolução como "lei”, engajandose, isto sim, no combate a interpretações que viam a evolução, nos termos de Darwin, como um plano de fundo a justificar o processo adaptativo.

Menand (2001, p. 357, 369) considera ainda que o cerne da psicologia jamesiana é ocupado pela tese do caráter adaptativo da mente, contrapondo-se às interpretações de filósofos empiristas como George Berkeley e John Locke, que também foram referências importantes para James. Esses dois filósofos acreditavam que a mente era uma entidade distinta dos fatos empíricos, mas James a entendia como uma função voltada para a adaptação. Como é de característico das reflexões jamesianas, as noções de mente e fato se apresentam em sua obra de modo articulado e contínuo. A preocupação com os fatos e a consideração pelos órgãos sensoriais como portas para o aprendizado associam-se ao entendimento da memória e do processo de aquisição de ideias como funções que permitem ao indivíduo armazenar e organizar suas vivências.

Essa compreensão do ser humano é respaldada na psicologia jamesiana, particularmente no conceito de "fluxo da consciência". A noção de fluxo decorre da característica natural da estrutura da mente humana que consiste em estar sempre em movimento, possuindo em seu interior o conhecimento, o sentimento, o desejo, a deliberação etc. O referido fluxo representa, em suma, a nossa vida interior. James (1899, p. 14) vê a consciência como um "fluxo, uma sucessão de estados, ou ondas, ou campos (ou que quer que mais lhes agrade chamá-la)". Um de seus aspectos relevantes é a sua constituição como uma "unidade prática", a partir da qual podemos "agrupar um campo com outros que sejam similares, chamando-o de um estado de emoção, perplexidade, pensamento abstrato, volição, entre outros" (idem, p. 19).

A origem desse conceito encontra-se em Principles, no capítulo denominado " $\mathrm{O}$ fluxo do pensamento", no qual James (1952, p. 146) conceitua que "o primeiro fato para nós, então, como psicólogos, é que qualquer pensamento é contínuo". Essa continuidade é o que melhor representa a ideia de fluxo, refletindo a associação que se estabelece entre as experiências do indivíduo, incluindo as que são realizadas com o próprio pensamento, como quando se opera com valores e outros elementos abstratos. A 
noção de fluxo retrata um processo que integra elementos externos, ideias armazenadas e fatos novos, sem a necessidade de um pensamento preexistente ou de sensações prévias; o que existe é um eu que pensa e um eu que sente, tendo sempre por base as relações estabelecidas com o meio, mediante um modo próprio de agrupar emoções, ideias e desejos nas ondas desse fluxo.

Bredo (2002, p. 14) entende que a "metáfora da onda" é adequada para significar o modo como os pensamentos se relacionam mutuamente, sem a necessidade de um “elemento externo". Qualificar o fluxo da consciência como ondas permite compreender os pensamentos como únicos e, ao mesmo tempo, como integrantes de uma mesma dinâmica que envolve o cérebro de uma pessoa, ou o seu sistema nervoso como um todo, e o meio com o qual ela se relaciona. Ao imaginarmos que as ondas do mar vão se formando constantemente, não sendo nunca iguais entre si, mas fazendo parte da mesma dinâmica das correntes oceânicas, podemos compreender a ideia jamesiana de fluxo da consciência. Diz Bredo: "Assim como cada onda é cercada por outra que a segue imediatamente e que ajuda a defini-la, assim também cada pensamento é cercado por uma 'franja' de outros pensamentos que formam seu plano de fundo ou contexto".

Como se pode notar, a noção de fluxo da consciência não diz respeito a um espaço determinado, delimitado; suas margens são de difícil demarcação, possuindo uma região central, regiões periféricas e, como veremos mais adiante em Variedades, uma região subliminal. A ideia de fluxo visa conceituar o modo complexo como as experiências, ideias e emoções são estocadas e estabelecem associações mútuas. Tal ideia remete a um universo plural composto por elementos inter-relacionados que são fluidos e estão em associações constantes, de diferentes modos, estabelecendo novas ideias e significados.

James (1899, p. 20) afirma que "a mais despretensiosa concepção do fluxo da consciência (...) será suficiente". Esse conceito tem um aspecto técnico altamente relevante para o ensino, que são os deslocamentos de "memórias de experiências passadas e pensamentos sobre coisas distantes, sentimentos de satisfação e de insatisfação, desejos e aversões, assim como outras condições emocionais" que caracterizam o aspecto fluido da composição de nossa consciência (idem, p. 17-18). Esses deslocamentos estão vinculados a "um tipo de unidade prática", a partir da qual podemos "classificar" um dado arranjo de elementos na consciência com outros que sejam similares (idem, p. 19). O fluxo da consciência tem duas importantes funções "conduz ao conhecimento, e conduz à ação" (idem, p.22) -, ambas conectadas por um 
mesmo propósito, que é a adaptação. Todo o nosso conhecimento diz respeito à ação, mesmo que em grau mínimo.

James (1899, p. 26-27) acredita que toda verdade, por mais abstrata que seja, influencia nossa ação. Ação, para ele, tem um "sentido amplo", podendo ser o "discurso", a "escrita", nossos posicionamentos favoráveis ou contrários a certos assuntos, "nossas tendências 'a partir' das coisas e 'em direção' às coisas, e nossas determinações emocionais". A caracterização do ser humano como um ser

prioritariamente prático é suficiente, segundo James (1899, p. 28), para que os professores abordem o "fenômeno psicológico dos jovens" em relação à sua "conduta futura" e considerem a "sua missão como se consistisse principalmente e essencialmente em treinar os alunos para o comportamento".

\section{Comportamentos, instintos e hábitos}

James (1899, p. 28) solicita aos professores que considerem sua profissão como voltada, prioritariamente, ao objetivo de preparar os aprendizes para a conduta, o comportamento. O filósofo refere-se a comportamento "no sentido mais amplo possível, incluindo todo tipo de reação adequada às circunstâncias", considerando as "vicissitudes da vida". Em termos jamesianos, comportamento indica capacidade e prontidão para enfrentar o que é novo, e é com base nessa conceituação que James estabelece que a educação "consiste na organização de recursos no ser humano, de poderes de conduta que devem adaptá-lo a seu mundo físico e social" (idem, p. 29).

$\mathrm{Na}$ visão jamesiana, cabe ao mestre conduzir a formação de recursos que habilitem os aprendizes a aproveitarem ao máximo tudo o que se apresente diante deles. Uma pessoa é educada quando tem condições de se conduzir em situações novas, nunca antes vividas, fazendo uso "de exemplos armazenados em sua memória e de concepções abstratas adquiridas”. Em suma, a educação pode ser definida, segundo James (1899, p. 29), como "organização de hábitos de conduta adquiridos e de tendências para o comportamento"

Bredo (2002, p. 25) adverte para o equívoco que reside na vinculação de James à tradição psicológica do behaviorismo, pois as suas ideias contrastam com as que são defendidas pela "maioria da psicologia behaviorista", grupo em que se situam Watson e Skinner, cujas teses foram direcionadas ao desenvolvimento de uma ciência voltada ao controle das pessoas. A concepção de James, embora "mais individualista" do que a de Dewey, é "igualmente democrática". Na conversa com os professores, James (1899, p. 
31) destaca ser necessário considerar os alunos como envolvidos em um processo de "aquisição, por eles mesmos, de capacidades de comportamento", nos diversos setores da vida - "emocional, social, corporal, vocal, técnico, ou que for".

Sua orientação enfatiza que a individualidade do aluno está presente no processo de ensino, o que significa valorização da pluralidade, aspecto ético que é constante nas proposições educacionais de James. Quando apresenta a máxima educacional de que “não há recepção sem reação, não há impressão sem expressão correlata”, James $(1899$, p. 33) refere-se não a uma reação ou expressão universal, mas a uma reação e expressão que se desenvolvem na experiência individual. Essa máxima é considerada por James "o primeiro fruto pedagógico de nossa concepção evolucionária da mente como instrumental voltado para o comportamento adaptativo" (idem, p. 36).

Os professores devem saber que os indivíduos não respondem em uníssono às impressões sensoriais, mas de modo diversificado e individualizado. Podeschi (2002, p. 67) entende a individualidade em James como uma forma de "enfatizar as intenções e atos individuais", porém não no sentido de que "a pessoa individual e seus direitos e necessidades sejam precedentes aos da coletividade", o que daria mostra de individualismo, não de individualidade, propriamente. Individualidade é o que caracteriza os indivíduos, "não unicamente pela singularidade de seus próprios desenvolvimentos, mas também pelo modo como eles são incorporados a um contexto social particular". Conclui Podeschi: "A individualidade, então, é produzida em meio a características particulares do mundo vivido, local onde o núcleo do eu está em contínuo processo de construção”.

Sempre ocupado em orientar as ações práticas dos professores, James enfatiza a importância de os mestres conhecerem a mente dos aprendizes para os estimular a reagir. "Nossa educação - diz James (1899, p. 38) - significa, em resumo, pouco mais que uma massa de possibilidades de reação, adquiridas em casa, na escola ou na instrução de assuntos”. A atuação do professor ganha relevância ímpar na concepção de James, pois cabe a ele a responsabilidade por produzir estímulos adequados que, juntamente com o esforço do aluno, devem resultar em novas reações e, consequentemente, novos conhecimentos, novos hábitos, novas condutas, o que significará, em suma, a consumação do objetivo primordial da educação - a transformação da pessoa. 
A compreensão desse processo remete diretamente à distinção entre reações adquiridas e inatas. ${ }^{9}$ James $(1899$, p. 38) explica que toda reação adquirida representa uma complicação, pois produz um conflito entre a nova reação e a inata, ou uma substituição desta por aquela. "A arte do professor consiste em trazer à tona essa complicação ou substituição, e o sucesso nessa arte pressupõe um conhecimento simpático das tendências à reação que são inatas" (idem, p. 39). É preciso auxiliar o estudante a estabelecer conexões significativas entre o que lhe é apresentado, de um lado, e seu próprio conjunto de ideias acumuladas, de outro. James conclui que é fundamental ficar atento às reações dos aprendizes, pois elas são práticas e, portanto, possíveis de serem percebidas e compreendidas. "Uma reação ruim é preferível a nenhuma reação; pois, se for ruim, o professor pode vinculá-la com consequências negativas que despertem o aluno para seu significado".

Na medida em que vão sendo trabalhadas pela educação, dentro de um processo que é estimulado pelo professor e consolidado pelos aprendizes, as reações vão sendo formadas. A consumação desse processo ocorrerá quando as reações inatas - "impulsos e instintos da infância" - forem substituídas por conceitos, ideologias, reflexões filosóficas, éticas, morais, etc., de tal modo que sejam transformadas em "objetos artificiais". As reações adquiridas se sobrepõem aos instintos inatos por meio do poder superior de raciocinar, fazendo com que o ser humano supere seus "simples comportamentos instintivos" (JAMES, 1899, p. 43). "As reações adquiridas devem se tornar habituais, onde quer que sejam apropriadas" (idem, p. 63).

“Toda a nossa vida - afirma James (1899, p. 64) - não é nada além do que uma massa de hábitos - práticos, emocionais e intelectuais - sistematicamente organizados para nossa prosperidade ou infortúnio". Os hábitos, que se relacionam tanto aos nossos vícios quanto às nossas virtudes, são classificados por James (idem, p. 34) em duas categorias: habit e rote. O primeiro é resultante de um processo de aprendizagem, no qual a ação retorna ao indivíduo e produz significado, experiência. O segundo é uma atividade mecânica, baseada na ideia de que basta ler e ouvir, ou meramente repetir sentenças, para que se efetue espontaneamente o aprendizado. As repetições são importantes, mas devem ser acompanhadas pela produção de significados.

\footnotetext{
${ }^{9} \mathrm{O}$ capítulo VII de Talks, intitulado "What the native reactions are" (O que são as reações inatas), lista as seguintes reações inatas: medo, amor, curiosidade, imitação, emulação, ambição, pugnacidade, orgulho, propriedade e construtividade.
} 
Bredo (2002, p. 25) esclarece que a noção de hábito na psicologia jamesiana é “orientada para a auto regulação", sendo associada à noção de individualidade. As sugestões feitas pelos professores devem resultar na configuração de hábitos, mas esta é uma realização dos próprios estudantes, ideia esta que repercute o princípio de pluralidade que recobre todas as proposições educacionais de James.

Em Principles, James (1952, p. 68) afirma que "nos animais selvagens, o comportamento rotineiro parece uma necessidade implantada desde o nascimento"; nos seres humanos "parece ser, em grande parte, o resultado da educação". Quando nos deparamos com seres vivos, o que imediatamente nos impressiona é que todos são formados por "um conjunto de hábitos". Nos animais, o que prevalece são os instintos inatos, mas nos humanos é diferente: os hábitos existem por causa da educação, podendo ser denominados "atos de razão".

Em suma, podemos concluir que educar, segundo James, consiste em identificar os instintos dos alunos para transformá-los em hábitos. Essa caracterização, no entanto, deve ser ampliada à luz do que diz Menand (p. 2001, p. 354) acerca da noção jamesiana de hábito: trata-se de um "conceito estatístico - previsível, repetível, habitual", mas as reações individuais são passíveis de serem antecipadas somente como "médias". Assim, entendemos que o trabalho educativo, segundo James, é um conjunto de práticas exercidas em situações que são, em boa medida, imprevisíveis; uma tarefa complexa que envolve descobrir os momentos mais adequados e as formas mais interessantes para estimular os aprendizes.

Cabe novamente destacar a relevância da função do professor, o que se exprime, segundo a concepção jamesiana, por uma série de atitudes e qualidades pessoais: o professor deve estar sempre atento, mostrando-se sensível, cuidadoso e perspicaz, tanto para apresentar o assunto da melhor maneira possível quanto para saber o momento certo de intervir. É assim, por meio da atuação desse profissional, que o estudante desenvolverá reações novas, hábitos novos, novas maneiras de ver o mundo e agir sobre ele; é assim que será viabilizado o processo da educação.

\section{Conceitos úteis aos professores}

Em Talks, James apresenta uma série de conceitos que, atrelados à noção de fluxo de consciência, podem contribuir para a consecução da complexa tarefa de educar. O primeiro deles é a "associação de ideias", processo que opera como plano de fundo de todas as demais funções da mente. Considerando a metáfora da onda, acima 
mencionada, James $(1899$, p. 80$)$ discorre sobre o que denomina "lei de contiguidade" e "lei de similaridade", cuja operação se efetua sempre que objetos novos são apresentados à mente. "Os objetos pensados no interior da onda que está chegando são os que numa experiência anterior estiveram próximos aos objetos representados na onda que está se afastando".

Esse fenômeno ocorre, por exemplo, quando lembramos o nome de um objeto ao vê-lo, ou quando o nome de determinado objeto nos faz lembrar de suas características, o que representa uma associação de ideias por proximidade. O caso do alfabeto auxilia na compreensão dessa lei, como explica James (1899, p. 80): se alguém disser “A, B, C", imediatamente a ideia de "D, E, F" nos vem à cabeça. Caso o objeto novo não induza uma associação imediata, por não ter relação direta com alguma experiência anterior, buscamos compreendê-lo por meio do estabelecimento de semelhanças. Em Principles, James (1952, p. 367) afirma sobre essa lei que, quando os objetos são "experienciados juntos", "tendem a se tornar associados na imaginação, de tal forma que quando qualquer um deles é pensado, os outros são possíveis de serem pensados também, na mesma ordem de sequência ou coexistência que antes".

$\mathrm{Na}$ educação, o conhecimento dos processos associativos deve resultar na organização de estratégias de ensino capazes de impulsionar o trabalho com reações e hábitos. James (1899, p. 84) explica que cabe aos educadores desarticular "associações erradas" e, ao mesmo tempo, "construir outras em seu lugar", o que significa "conduzir as tendências associativas para canais mais adequados". O professor deve apresentar um mesmo assunto das mais diferentes formas, pois assim aumenta a chance de os alunos estabelecerem associações mentais, tanto por proximidade quanto por semelhança.

Os conceitos de "interesse" e "atenção" enquadram-se como operações mentais igualmente úteis ao trabalho docente. James (1899, p. 92) explica que crianças desenvolvem interesse imediato por aquilo que experimentam sensorialmente, não ocorrendo o mesmo com as coisas abstratas, apresentadas verbalmente: "A criança sempre irá prestar mais atenção no que o professor faz do que naquilo que o professor diz". Conhecendo o processo de associação de ideias, o educador deve utilizar aquilo que está no campo do interesse atual do aluno em favor daquilo que o conteúdo programático institui que deva ser adquirido.

Para que a aprendizagem se efetive, James esclarece que não basta o empenho organizativo do professor; é preciso contar, igualmente, com a atenção do aluno, ou seja, com a concentração de seu interesse no assunto em pauta. A atenção pode ser 
passiva, espontânea, como pode também demandar esforço, deliberação. A primeira se estabelece com as coisas que são interessantes em si mesmas, ao passo que a segunda necessita de estímulo constante para não se perder: "o assunto deve ser abordado de modo a apresentar novos aspectos de si mesmo; incitar novas questões; ou seja, mudar" (JAMES, 1899, p. 103). Assim, é possível mobilizar o assunto para as regiões centrais do fluxo da consciência e despertar "um conjunto de experiências a serem aprendidas a partir disso" (idem, p. 107).

Esse novo conjunto de experiências promove mais associações; quanto maior for o número de associações, ou o poder de associar, mais se aperfeiçoa a "memória" conceito que, juntamente com os anteriores, possui especial relevância para o trabalho docente. A memória é uma consequência do fato de a mente ser uma "máquina de associações" (JAMES, 1899, p. 116). Com esta afirmação, James se opõe frontalmente à ideia de memória como entidade, preferindo tratá-la como resultante do processo associativo efetuado pela mente: uma "memória educada depende de um sistema organizado de associações" (idem, p. 120).

"Não pode haver melhoria de nossa faculdade geral ou elementar da memória: pode haver melhoria apenas a partir de sistemas específicos de coisas associadas" (JAMES, 1899, p. 123). James considera essa tese diretamente aplicável à prática pedagógica, que deve promover articulações entre os objetos memorizados e os seus respectivos significados. O exercício da repetição é condenável somente se for limitado à mera reprodução mecânica de palavras, o que evidentemente separa o aprendiz das coisas significadas, e os significados são fundamentais para constituir o estoque de ideias que habilita o indivíduo a deliberar diante das emergências apresentadas pela vida (idem, p. 148).

O conceito de "apercepção" é estreitamente relacionado à deliberação, a qual, por sua vez, depende do estoque de ideias ou do conjunto de significados, compreendidos segundo nossa capacidade de memória. A "massa aperceptiva" é o que responde pela representação de nosso estoque de ideias. James (1899, p. 158-159) explica que um estímulo, ao adentrar à mente pelos órgãos sensoriais, interage com $o$ estoque de ideias ali existente; as ideias, que são majoritariamente relativas a significados e concepções, tentam enquadrá-lo em alguma das classificações preexistentes. Assim, é frequente que o novo estímulo seja comprimido pelo estoque de ideias para causar o mínimo de perturbação e o máximo de harmonização - processo comunicado pela "lei da economia". 
Cada indivíduo irá deliberar de acordo com o direcionamento assumido pela nova impressão, uma vez submetida ao estoque de ideias. Em busca de superar uma situação problemática, a mente vai na direção de uma "concepção menos perturbadora", mas James (1899, p. 163) adverte que seria preferível se houvesse interação como interpretações diversas, de modo a ampliar o estoque de ideias mediante certo esforço intelectual. Essa última alternativa, que pode ser incentivada pelo professor, remete ao conceito de "vontade", processo que se desenvolve quando operam "sistemas de ideias conflitantes", o que, por sua vez, "depende de possuirmos um amplo campo da consciência" (idem, p. 175).

A atuação dos mestres tem consequências no âmbito da vida social, pois as pessoas que possuem um campo de consciência mais ampliado, devido à presença de maior número de ideias associadas, possuem também a capacidade de desenvolver ideias inibidoras de certos impulsos instintivos. Contrariamente, aqueles cujo campo de consciência é habitado por poucas ideias associadas tende a ficar mais sujeito a tais impulsos, o que pode resultar em atitudes violentas (JAMES, 1899, p. 180).

\section{Conversando com estudantes}

Após a conversa com os professores, examinada na primeira seção deste capítulo, Talks apresenta as conferências feitas por James aos estudantes, nas quais a temática dos valores morais assume o primeiro plano. Esta segunda parte do livro, intitulada Talks to students, ocupa bem menos páginas do que a anterior, sendo composta por apenas três seções.

\section{A função das emoções}

O fio condutor do discurso jamesiano em Talks to students são as emoções, os sentimentos, as paixões. James (1899, p. 199) considera que o sentimento tem o poder de nos fazer escolher este ou aquele caminho; se não possuíssemos sentimentos, "perderíamos todas as nossas preferências e desgostos de uma vez, e seríamos inaptos para apontar para uma situação ou experiência na vida mais valiosa ou significante que outra" (idem, p. 229). Fica assim evidente a sua importância para a vida, pois os sentimentos estão associados aos significados que estabelecemos para as coisas; além disso, realçam nossa dificuldade em compreender os sentimentos e significados dos outros. 
Segundo James (1899, p. 265), reside nisso “a base para a tolerância social, religiosa e política. (...) A primeira coisa a aprender nas relações com os outros é não interferir no seu modo particular de ser feliz, com a condição de que esses modos não interfiram com violência nos nossos". É assim que o indivíduo pode tornar sua vida mais significativa. James afirma que não é possível controlar o que sentimos, mas é possível controlar a maneira como agimos (idem, p. 201). $\mathrm{Na}$ medida em que estabelecemos condutas que restringem a abertura total para as paixões, conseguimos controlar nossos sentimentos.

A primeira seção de Talks to students, "The gospel of relaxation", discorre sobre as possibilidades de controle da conduta, com vistas a estimular sentimentos de cunho inclusivo que sirvam de modelos para o progresso da sociedade norte-americana. A palavra "gospel", que pode ser traduzida por evangelho, associa-se às investigações feitas pelo filósofo acerca de escritos de "devoção religiosa" que "reiteram a máxima de que devemos deixar nossos sentimentos fluir livremente, sem dedicar muita atenção a eles" (JAMES, 1899, p. 202). James explica que tais escritos transmitem a ideia de que o que realmente importa são nossos propósitos e nossa vontade. Citando Hannah Whitall Smith, James conceitua que nossas emoções "não são indicadores de nosso estado de espírito, mas de nosso temperamento e de nossa condição física". ${ }^{10}$

James (1899, p. 33) afirma que "não há recepção sem reação, não há impressão sem expressão correlata", e que dessa expressão, atitude, ação, chega uma onda correspondente a uma impressão final, uma avaliação que o indivíduo faz de todo esse processo. Assim, torna-se possível cultivar um estado interior desejado, imbuído de bons sentimentos, com base nas nossas ações no mundo. As práticas esportivas ilustram a correlação entre ação e estado de espírito, pois elas são meios que conduzem a um espírito moral "saudável e caloroso" (idem, p. 205). O treinamento físico e o treinamento intelectual, propiciando o bem-estar moral, correspondem a duas metades proporcionais de uma boa educação.

James (1899, p. 212) indica o papel do "impulso imitativo", que deve ser trabalhado em prol das relações entre o estado interior do individuo e suas ações, visando ao progresso social. James afirma que "invenção e imitação, juntas, formam, pode-se dizer, toda a urdidura e trama da vida humana, na medida em que esta é social”. O excesso de ansiedade, intensidade, pressão e agonia na sociedade norte-americana é

\footnotetext{
${ }^{10}$ James registra o nome da autora e o título da obra, The Christian's secret of a happy life, sem indicar sua referência bibliográfica completa.
} 
resultante de "maus hábitos" que são "reproduzidos pelo costume" e que "nascem da imitação de modelos ruins e do cultivo de ideais pessoais falsos". O cerne desse problema, segundo James (idem, p. 214), está "nos sentimentos absurdos de pressa e falta de tempo, na falta de fôlego e na tensão, na ansiedade característica e na preocupação com resultados", assim como na "falta de harmonia interior e de tranquilidade".

A solução deve ser buscada na origem desses sentimentos: "Se maneiras e gostos imorais são culpados por isso, eles precisam ser mudados", para o que devem ser forjados e projetados exemplos fundamentados na calma, na harmonia, na dignidade (JAMES, 1899, 216-217). As condições para o lançamento de um novo exemplo a ser imitado estão relacionadas com os traços internos de quem engendra o impulso. Quanto menos uma pessoa se preocupa em ser imitada, mais ela tende a ser imitada.

Para engendrar uma conduta com maior possibilidade de ser imitada, é importante que o indivíduo esteja em condição de realizar associações de ideias. James (1899, p. 220) pontua que se "desejamos que nossas correntes de ideação e volição sejam abundantes, variadas e efetivas, devemos formar o hábito de libertá-las da influência inibidora da reflexão sobre elas”. Esta afirmação causa certa estranheza, à primeira vista, uma vez que a reflexão, em acordo com o conceito jamesiano de vontade, é um momento de ponderação entre impulsos e inibições, mas é preciso notar que James refere-se aos sentimentos inibidores que produzem a "preocupação egoísta com seus resultados".

James (1899, p. 218-219) ilustra essas proposições com o exemplo dos melancólicos e dos santos que experimentam episódios de êxtase, afirmando que um "sentimento forte sobre si mesmo tende a inibir a associação livre entre suas ideias objetivas e suas atividades motoras". A tensão entre os sentimentos e a ação está no cerne da formação do hábito desejado, da conduta que permita ao indivíduo incluir em seus ideais os ideais dos outros. Os melancólicos se sentem "ameaçados", "culpados", "condenados" e "aniquilados", o que corresponde à formação de sentimentos que inibem seus "processos associativos". Contudo, não é necessariamente "o mero fato das emoções dolorosas" o que caracteriza a inibição da associação de ideias, pois "emoções alegres" também produzem tal paralização (idem, p. 220).

James (1899, p. 221) entende que sentimentos como "a prudência, o compromisso, a dignidade, as emoções de ambição e as emoções de ansiedade" possuem grande importância em nossas vidas. Porém, devemos deixá-los de lado 
quando estamos "tomando nossas resoluções gerais e decidindo sobre nossos planos de ação". Quando a decisão é definida e estamos prestes a executá-la, devemos relaxar, não acentuar nossa preocupação com os resultados; devemos afrouxar "nosso intelecto e nosso maquinário prático, e deixá-los correr livremente”.

James (1899, p. 222) conclui o exame desse tema traçando um paralelo com a profissão do professor, que deve tornar acessível o assunto a ser ensinado, confiando em sua "espontaneidade" e afastando para longe "todos os demais cuidados". Em contraste com as volumosas atribuições do ofício docente indicadas no início de Talks to teachers, o filósofo defende sua doutrina do relaxamento por meio de uma metáfora: "Assim como a corrente de uma bicicleta pode estar muito apertada", dificultando o ato de pedalar, "assim também pode estar a preocupação e a consciência de um indivíduo, impedindo o correr de sua mente".

\section{$O$ controle dos sentimentos}

A ideia de educação como responsável pela organização de hábitos de conduta e pelo direcionamento de tendências de comportamento - ideia desenvolvida por James na conversa com os professores - amplia-se, na conversa com os estudantes, mediante uma reflexão acerca do papel dos sentimentos e dos modelos úteis à sociedade. $\mathrm{O}$ conceito jamesiano de vontade, associado ao processo de deliberação dele decorrente, indica um caminho para os jovens obterem controle sobre sua conduta, podendo afastar sentimentos indesejados por meio da própria ação (JAMES, 1889, p. 220).

Conforme a explicação dada por James (1889, p. 175) aos professores, o conceito de vontade diz respeito ao fato de nossa mente ser composta por impulsos para ação e impulsos inibidores. ${ }^{11}$ A deliberação diante desses fatores depende de um esforço do indivíduo para avaliar hipóteses, estabelecer associações e traçar possíveis consequências. Os sentimentos habitam esses impulsos, sendo responsáveis por nossos posicionamentos, nossa ação e nossos juízos de valor. A ação e o sentimento são vinculados; "regulando a ação, que está sob controle direto da vontade", os estudantes poderão "regular indiretamente o sentimento, que não está sob controle direto da vontade" (idem, p. 201).

\footnotetext{
11 Essa afirmação também pode ser encontrada no capítulo denominado "Will" de The principles of psychology (JAMES, 1952).
} 
Para evitar que os juízos e a ação se submetam aos sentimentos, é preciso não somente identificar as paixões, como também esboçar um novo plano de conduta, contrário ao que sugere a emoção. Assim, torna-se possível regular o que sentimos; nossas paixões não são corretas nem erradas, elas existem pelo fato de sermos seres humanos, tanto do ponto de vista biológico quanto social (JAMES, 1899, p. 199). A questão central é o poder que as paixões possuem para determinar certas condutas, principalmente aquelas que são indesejadas, considerado o contexto em que se insere o indivíduo.

A proposição moral de James (1899, p. 200) para os jovens consiste em admitir que não há preceito "melhor ou mais geralmente útil" do que aquele que nos sugere prestar "mais atenção ao que fazemos e ao que expressamos, e não muito àquilo que sentimos". Embora atribua elevado valor ao indivíduo na empreitada de regular suas ações, James reconhece haver uma pressão do contexto, mas, como aponta Podeschi (2002, p. 67), "Embora seja consciente dessas forças do meio social sobre o indivíduo, a fillosofia de James está centrada nos esforços do indivíduo para resistir a elas”. Para que a ação siga na direção desejada, James (1899, p. 66-67) sugere que, até que a conduta esteja solidamente estabelecida, devemos ter a cautela de não agir de outro modo, pois ações precipitadas podem impedir a solidificação do hábito almejado.

Ainda sobre a afirmação de condutas desejadas, James (1899, p. 224) diz aos estudantes que a "tensão moral" pode conduzir a sentimentos de ansiedade, culpa e melancolia, e que a "fé religiosa" pode auxiliar na superação desse estado negativo, contribuindo para o estabelecimento de atitudes morais significativas. "A pessoa verdadeiramente religiosa é apropriadamente inabalável e cheia de equanimidade, e tranquilamente pronta para qualquer compromisso que o dia possa apresentar".

A expressão de "tensão moral” corresponde, no vocabulário jamesiano, a possibilidades criativas engendradas pela livre associação de ideias, constituindo elemento importante para o trabalho do professor, que, ao identificá-la, pode recorrer a estímulos diversos para atingir e mobilizar os estudantes em direção aos propósitos da aula. A tensão moral pode ser compreendida entre as expectativas que produzimos diante de determinadas situações, expectativas que podem formar bloqueios, impedimentos e, assim, produzir ansiedade. A referida expressão transporta a ideia de dureza, rigidez, algo que está no limite e que, por sua inflexibilidade, não permite desenvolver ações. O relaxamento da tensão, que pode ser propiciado pela religiosidade, nos prepara para reconhecermos as diferenças que habitam o mundo. 


\section{O reconhecimento do outro}

O tema das diferenças ocupa o eixo da segunda seção de Talks to students, dedicada aos estudantes. James (1899, p. 229) explica que a dificuldade para reconhecer os sentimentos do outro é como uma "cegueira" que nos impede de enxergar emoções diferentes das nossas. A tal cegueira constitui um efeito colateral de nossa condição de seres práticos, a qual nos impele a desenvolvermos certa "apatia" diante de tudo o que não seja a nossa felicidade particular (idem, p. 241). Disso decorre "a estupidez e injustiça de nossas opiniões, na medida em que lidam com a significância de outras vidas"; daí decorre também a "falsidade de nossos julgamentos, na medida em que presumem decidir de modo absoluto sobre o valor das condições e ideais de outras pessoas" (idem, p. 230).

Os sentimentos possuem relação íntima com a verdade, segundo James (1899, p. 231), pois, “onde quer que exista conflito de opinião e diferença de visão, somos compelidos a acreditar que o lado verdadeiro é o lado que sente mais, e não o lado que sente menos". Mas é preciso notar que o julgamento perde seu valor quando se fecha para o sentimento daquele que é julgado, espaço em que se enraíza o significado da conduta. Para James (idem, p. 241), "apenas em alguns sonhadores piedosos, alguns filósofos, poetas ou romancistas, ou quando o homem prático se apaixona”, é que se torna possível a ampliação dos horizontes de ideais e a contemplação dos significados e sentimentos dos outros. Só então "todo o sistema de valores comuns é desconstruído, e o nosso eu é despedaçado, tendo seus interesses estreitos destruídos, e um novo centro e uma nova perspectiva são encontrados".

Garrison (2002, p. 27) entende que, no universo pluralista da filosofia de James, estar conectado com o outro envolve "ação criativa", "inteligência" e uma autêntica "ação moral". Denotando os elementos transcendentes que permeiam tais ações, Garrison as vincula à dimensão religiosa dos indivíduos, enfatizando seu "aspecto potencialmente numinoso". Para Garrison (idem, p. 37), o reconhecimento e a ampliação de significados que os poetas, profetas, filósofos e romancistas atingem está relacionado ao fato de perceberem "a riqueza da vida, tanto as suas próprias como a dos outros (...) Para ser mais, alguém deve ver mais, mas ver envolve fazer, sentir, e, só ao fim, conhecer". É preciso transcender "nosso círculo estreito de interesses e transformar nossas vidas. A poesia profética comunica novas possibilidades, novos significados, e uma visão mais ampla; ela nos ajuda a curar nossa cegueira rudimentar”. 
A filosofia jamesiana sugere que o estudante desenvolva uma "visão ampla" dos significados internos dos outros, de modo a integrá-los entre os seus próprios significados, com vistas não a fazer deles as suas próprias metas, mas a enriquecer seus objetivos próprios, procedendo assim como "o poeta" que "nunca poderia explicar logicamente ou a partir de concepções articuladas" aquilo que o sensibiliza e impele a agir (JAMES, 1899, p. 244). Quem possui essa visão ampla, geralmente amparada na fé religiosa, é capaz de alimentar "a alma dos outros", a preenchendo com a sua própria "riqueza interior" (idem, p. 245).

$\mathrm{O}$ momento em que o indivíduo atinge essa visão mais profunda não possui correspondência nos "padrões usais dos valores comerciais", mas nos "sentimentos de entusiasmada significância (...) que engendra em alguém” (JAMES, 1899, p. 247). James caracteriza esse sentimento como "espetáculo da presença do mundo", representando a forma como o indivíduo reconhece a sua "incomensurável significância e importância" (idem, p. 254). Não há "receita" para alcançar esse tipo de sentimento; sendo um "segredo", ele "geralmente surge de maneiras misteriosas", na dependência de "a alma ser apanhada, de ter suas correntes de vida absorvidas pelo que é apresentado" (idem, p. 257).

E não se pense que as pessoas de nível acadêmico mais elevado sejam mais capazes de compreender esse sentimento. James (1899, p. 257) acredita que a educação das elites é carregada de "concepções abstratas" e "verbosidades", e que isso "nos faz crescer cegos como pedras e insensíveis a bens e riquezas mais gerais e elementares". O que conta para o cultivo de valores e ampliação de horizontes, em associação com as abstrações no âmbito educacional, são os bens proporcionados ao corpo por atos de “observar, cheirar, saborear, dormir, ser corajoso e agir". Para "mostrar o bom da vida para muitos pessimistas" de elevada educação, é preciso "descer a um nível mais profundo e primitivo" (idem, p. 258).

James (1899, p. 263) conclui que o essencial consiste em "sentir o próprio segredo interno", cuja importância é inefável. Eis a mágica "dessa misteriosa vida sensorial", que proporciona "felicidade suprema". Ela nos "impede de pronunciar a insignificância de outras formas de existências que não as nossas próprias; e nos impele a tolerar, respeitar e perdoar aqueles que vemos inofensivamente interessados e felizes à sua própria maneira”, mesmo quando são ininteligíveis para nós (idem, p. 264).

É certo que nem todas as pessoas são capazes de estabelecer relações profundas com o outro, mas aquelas que o fazem possuem "enorme capacidade para amizade e 
para se deleitar com a vida dos outros; e tais pessoas sabem mais da verdade do que saberiam se seus corações não fossem tão generosos" (JAMES, 1899, p. 267). Como consequência de sermos seres práticos, possuímos uma "visão curta"; por isso, "nossos segredos internos devem permanecer, em sua maior parte, impenetráveis aos outros”. Reconhecendo essa limitação, James aconselha utilizarmos "o senso de nossa própria cegueira para nos tornarmos mais cautelosos" ao estabelecer juízos de valor sobre os outros (idem, p. 268).

\section{A religiosidade e o significado da vida}

James (1899, p. 268) afirma ser possível "tornar a nossa tolerância menos caótica" e, consequentemente, tornar a nossa vida mais significativa. Esse é o tema da terceira e última parte da conversa do filósofo com os estudantes, na qual se lê que o mundo em que vivemos é cruel, cheio "de força e vigor, intensidade e perigo" (idem, p. 271). O que caracteriza a história do ser humano é "a eterna batalha dos poderes de luz contra os de escuridão", e o que as "nossas emoções humanas parecem solicitar é a visão da luta continuada", pois, no "momento em que os frutos são comidos, as coisas se tornam desprezíveis"; a natureza humana permanece viva quando se vê "tensionada ao extremo e exausta", lutando e perseguindo novos objetivos, ainda mais difíceis - eis “o tipo de coisa cuja presença nos inspira, e a realidade disso parece ser a função de todas as formas elevadas da literatura e das belas artes", que trazem tal sensação à vida (idem, p. 272).

Além da literatura e das artes, James (1899, p. 274) considera a vida comum a nossa maior fonte de inspiração. Observando a "vida diária das classes trabalhadoras", ele encontra o antídoto à "cegueira ancestral" que nos afasta do valor moral responsável por ampliar a nossa visão. Ao desenvolvermos essa percepção, cai por terra a nossa escala de valores, abrindo-se o espaço para nos sensibilizarmos com a vida rotineira (idem, p. 275).

Reportando a sua própria experiência, James (1899, p. 277) narra que essa percepção ampliou a sua "visão religiosa", a compreensão de que o que realmente importa na vida é "o fato comum de estarmos aqui, numa incontável multidão de servos da vida, cada indivíduo encerrado em suas próprias dificuldades, com as quais devemos lutar". O reconhecimento desse fato nos permite entender o que nos eleva e o que nos rebaixa: nos elevamos quando nos ocupamos com "nosso significado interior" e nos 
rebaixamos quando nos preocupamos apenas com "a glória externa e exibição" (idem, p. 278).

No decorrer da história, a "cegueira" sempre retorna à sociedade, de diferentes maneiras, fazendo-se necessária a existência de "profetas religiosos", como Buda, Cristo, Rousseau e Tolstoi, que tornam o mundo "mais humano" e permitem a continuidade da "religião da democracia" (JAMES, 1899, p. 278). Para alcançar a riqueza interior e aumentar a fé religiosa, são necessários fatores internos e externos, explica James (1899, p. 284-285), que podem surgir em qualquer lugar, tanto nos indivíduos de educação mais complexa e abstrata como naqueles que não tiveram acesso ao ensino escolar, tanto das universidades e nos círculos sociais das elites como nos meios em que se realizam trabalhos de subsistência. A "significação total do ser humano" depende da combinação de dois elementos: "a sua virtude interior $e$ o seu ambiente externo".

James (1899, p. 291) exibe especial admiração pela classe trabalhadora, dizendo que há monumentos erguidos em homenagem a soldados, mas não a trabalhadores, mesmo sabendo que "nossas cidades são de fato fundadas sobre os seus corações pacientes e as suas costas e ombros persistentes". Quando dizemos que os soldados devem ser reverenciados por seguirem ideais e negamos esse reconhecimento aos trabalhadores, mostramos insensibilidade à combinação de esforço, suor e dedicação com significados internos válidos e completos.

Para James (1899, p. 292), um ideal é "algo intelectualmente concebido", do qual "não somos inconscientes"; algo que possui "perspectiva, elevação e resplendor, caminhando em consonância com todos os fatos intelectuais"; por fim, um ideal deve conter "novidade". Sendo assim, independentemente da forma, todos possuem ideais ideais "pessoais ou gerais, seguros ou equivocados, pequenos ou elevados". E os ideais devem ser ampliados, tanto para o nosso próprio benefício como para reconhecimento dos ideais dos outros, e nisto reside o potencial da educação que, ampliando nosso "horizonte e perspectiva, é um meio de multiplicar nossos ideais e trazer novos ideais para nosso alcance" (idem, p. 293).

James (1899, p. 296) observa que as "conclusões nunca podem ser precisas" quando envolvem "significância" e "valor". A fé religiosa, os ideais e as atividades virtuosas podem indicar um caminho para termos "um pouco mais de humildade, (...) tolerância, respeito e amor pelos outros". Esse caminho conduzirá a "certa felicidade interior, com o aumento da importância de nossa vida comum", uma felicidade que 
constitui "uma inspiração religiosa e um elemento de saúde espiritual", cujo valor é maior do que as informações conceituais e técnicas que podemos encontrar nas ciências (JAMES, 1899, p. 296-297).

$\mathrm{Na}$ mensagem final aos estudantes, James (1889, p. 299) enfatiza que "o significado sólido da vida sempre será a mesma coisa eterna - nomeadamente, o casamento de algum ideal não habitual, não importa o quão particular seja, com alguma fidelidade, coragem, resistência". 


\section{II - O VALOR DA EXPERIÊNCIA RELIGIOSA}

No primeiro capítulo deste trabalho foram apresentadas as proposições de William James para a educação, destacando primeiramente as suas ideias acerca do ensino, apresentadas na conversa com professores. Posteriormente, no diálogo travado com estudantes, pudemos entender as suas reflexões no campo que se aproxima de uma filosofia moral, amparada em uma filosofia pluralista, como indicado pelo próprio autor no prefácio de Talks to teachers (JAMES, 1899, p. v).

No exame de Talks, procuramos manter em nosso horizonte a concepção jamesiana de ensino como arte, buscando, tanto na primeira como na segunda partes daquele livro, elementos que pudessem projetar alguma luz sobre a referida proposição. Da exposição dirigida aos estudantes, destacamos as referências do autor ao poder das paixões sobre nossas escolhas e atribuições de significados; o controle ou comedimento das paixões pela conduta; o papel da fé religiosa diante da tensão entre paixões indesejadas e o empreendimento de condutas que lhes são contrárias; a capacidade de reconhecer e incluir em nossos ideais os ideais alheios; e a inspiração advinda de simples experiências cotidianas que pode nos conduzir a uma vida mais significativa.

Como pudemos notar no capítulo precedente, James recorre ao universo da religiosidade para sustentar suas proposições morais com vistas ao progresso social, à busca de modelos imitativos que auxiliem nesse progresso e à formação de uma sociedade inclusiva que resulte em uma forma de vida mais plena de significados. Ainda mantendo em nosso horizonte a ideia de ensino como arte, julgamos relevante aprofundar o tema da religiosidade em James por meio da análise do livro publicado dois anos após Talks, em 1902, fruto de duas séries de palestras realizadas pelo autor em Edimburgo, Escócia, no roteiro das Conferências Gifford. ${ }^{12}$

Trata-se de As variedades da experiência religiosa, cujo subtítulo indica ser um estudo sobre a natureza humana, em que James (1995) realiza uma análise filosófica do tema em pauta, amparando-se nos conhecimentos científicos da psicologia e no estudo de relatos de experiências de vários indivíduos. Seu intuito era problematizar e organizar os conhecimentos que a filosofia da religião havia produzido até aquele

\footnotetext{
${ }^{12} \mathrm{O}$ objetivo inicial das Gifford Lectures, criadas no final do século XIX nas universidades escocesas de Edimburgo, Glasgow, St. Andrews e Aberdeen, era o de "promover e difundir o estudo da Teologia Natural, no sentido mais amplo do termo - em outras palavras, o conhecimento de Deus" (www.giffordlectures.com < acesso em 06/11/2015>).
} 
momento, com o propósito de situar a religiosidade entre os elementos passíveis de compreensão científica pela psicologia e de tratamento filosófico sistematizado.

Em Variedades, James se ocupa em estudar o fenômeno religioso, o qual, sob o olhar da psicologia, constitui elemento relevante para a ampliação dos conhecimentos relativos à constituição mental do ser humano. Para isso, recorre à filosofia para problematizar e tecer indagações acerca do que é verificado pela abordagem psicológica, e, por fim, estabelece dois conceitos - estados místicos de consciência e santidade - que exprimem as formas concretas da experiência religiosa.

Com base na psicologia formulada em Principles, Variedades busca apresentar uma filosofia que, orientada pelo método pragmatista e pelas concepções pluralistas jamesianas, seja capaz de compreender um tipo particular de experiência, qualificada como religiosa (MIEDEMA, 2002; NIEBUHR, 1998). Não se trata de uma experiência obtida na esfera de uma religião específica, nem mesmo necessariamente oriunda de uma doutrina dotada de preceitos filosóficos, ritos e procedimentos preservados pela tradição. O foco de James são as experiências pessoais relacionadas com o divino, as quais repercutem em um processo de conscientização, produção de novos significados e ordenamento de condutas específicas.

Em Variedades, James (1995, p. 36) define religião como "sentimentos, atos e experiências de indivíduos em sua solidão, na medida em que se sintam relacionados com o que quer que possam considerar divino". A percepção de estar envolvido por uma força superior, primitiva, é o que se denomina divino, um processo que conduz a pessoa a agir "solene e gravemente", sempre com respeito. Para James (idem, p. 33), a noção de divino não é necessariamente vinculada à ideia teísta da religiosidade, à crença na existência de um Deus; não é preciso ser adepto de uma doutrina específica para ter uma experiência religiosa. A dimensão divina diz respeito ao que é "semelhante à divindade", àquilo que o indivíduo designa como divindade.

Isso que James qualifica como semelhante à divindade não deve ser entendido, segundo Shook (2002, p. 113-114), com base nas reflexões do filósofo sobre a concepção de verdade, na qual se encontra a ideia de que "cada pessoa tem sua própria verdade, porque uma pessoa só pode viver suas próprias experiências" - afirmação que se conhece como "subjetivismo". Shook considera que aquilo que James caracteriza como verdadeiro refere-se "à relação entre uma ideia na mente e algo que existe fora dessa ideia". 
Niebuhr (1998, p. 224) entende que o tipo de experiência que James denomina religiosa envolve "sensação, percepção, sentimentos, oração, mudanças de ânimo, libertação do medo e alterações de atitude", embora não se resuma a isto. Ao enfatizar a experiência dos indivíduos, a abordagem de James se aproxima mais de "inferências" decorrentes de "um estudo empírico da vida religiosa". Embora seja apresentada de modo "pouco rigorosa", a noção jamesiana de experiência sugere um "conhecimento" dotado de "consequências práticas" (idem, p. 218-219). Uma complexa rede conceitual faz de Variedades "um livro de transição, apresentando descrições e julgamentos espirituais, psicologia e uma metafísica incipiente entrelaçados na mente de James" (idem, p. 223).

O desenho teórico da obra revela a pluralidade que James advoga não apenas no âmbito de seu objeto de estudo, mas também na própria estruturação de sua análise. A escolha de Variedades é propícia à nossa pesquisa por conter uma avaliação filosófica sobre o valor das crenças, bem como por oferecer uma abordagem psicológica acerca dos processos mentais envolvidos na experiência religiosa. Neste capítulo, nossa meta consiste em estudar as teses de James sobre a referida experiência, com vistas a reunir elementos que nos auxiliem na compreensão da ideia jamesiana de ensino como arte, o que será objeto da última seção deste trabalho.

\section{As diretrizes da investigação}

Com base em relatos feitos por diversas pessoas em diferentes tempos e lugares, James (1995, p. 16) realiza uma investigação especialmente dedicada a entender os sentimentos e impulsos que auxiliam na análise e avaliação da experiência religiosa. Seu objetivo não é encontrar verdades, mas revelar os significados construídos nas expressões de pessoas religiosas, bem como nas condutas associadas a essas expressões, indicando suas dimensões prática e moral. Para realizar essa investigação, o filósofo recorre a um tipo de juízo, o "juízo espiritual”, critério adotado para delinear as peculiaridades das expressões religiosas que conferem valores e significados para a vida.

Durkheim (2004, p. 147) explica que James não recorre ao "método dogmático", pois busca fundamento unicamente nos resultados da investigação, não em princípios apriorísticos. O processo jamesiano para identificar o valor de uma expressão religiosa pode ser esclarecido por uma analogia: "para saber o valor de uma árvore, não consideramos suas raízes, mas os frutos que produz". A indagação filosófica realizada 
por James é uma aplicação de seu método pragmático, tendo por objetivo atribuir um sentido à ação, a concebendo no interior de "um sistema de valores", encarnada "no mundo onde vivemos" (idem, p. 146).

Childs (1959, p. 293) corrobora essa interpretação, dizendo que o método pragmático de James visa "elaborar uma interpretação empírica da natureza e do sentido da experiência religiosa”. O próprio James (1995, p. 25) observa que o juízo espiritual é um critério empírico, orientando pela ideia de que o verdadeiro significado da expressão religiosa não deve ser buscado em sua origem, mas na maneira como atua perante o todo.

O juízo espiritual é um juízo de valor concebido por James (1995, p. 22) em oposição ao juízo existencial, ambos representantes de diferentes ordens de inquérito na esfera da lógica. O primeiro se encarrega de apreciar os valores de uma experiência com base em seu resultado, focalizando seu significado nas relações com o todo, ou seja, com o contexto, as condutas, as relações sociais, a moral. O segundo busca qualificar a experiência com base em suas causas, sua origem. Para esclarecer que as origens de uma expressão religiosa não são responsáveis por definir sua qualidade, James refuta teorias que sustentam a causação orgânica como fonte das expressões religiosas, o que levaria a caracterizá-las como patológicas.

Com base no critério do juízo espiritual, James (1995, p. 17) destaca somente as expressões individuais em pessoas que considera "gênios" do universo religioso. Tais indivíduos são responsáveis por fixarem os padrões do que hoje conhecemos como religião, ou seja, a forma institucionalizada de uma crença espiritual. A religião, assim definida, não é objeto da investigação de James, cujo interesse é voltado unicamente para as expressões individuais mais extremas, pois é nelas que se evidencia mais marcadamente a experiência religiosa.

No âmbito da religiosidade dos indivíduos, o que se verifica é o valor de suas expressões, significados e conduta com base em juízos espirituais. Esses juízos devem operar sobre o "sentimento imediato" em suas relações empíricas com as expressões religiosas, cabendo investigar a existência de vínculos com as necessidades morais - o que abrange a cultura, o ambiente e a sociedade - e com tudo o que se admite como verdades garantidas, enraizadas no modo de vida e na visão de mundo (JAMES, 1995, p. 20). São essas as relações que constituem a experiência, na qual James (idem, p. 24) identifica os seguintes aspectos: sentimento e emoção, entendidos no registro do imediato; operação intelectual, caracterizada por um esforço do indivíduo, indicando 
razoabilidade; reconhecimento do contexto e dos demais indivíduos, no interior da dimensão moral que é contextual, dizendo respeito às associações entre indivíduos.

\section{O sentimento religioso}

O ponto central da investigação conduzida pelo critério do juízo espiritual é o que James (1995, p. 29-30) denomina "sentimento religioso", elemento fundamental para atribuir significado da experiência em questão, bem como situá-la no âmbito da experiência religiosa. Tal sentimento não se apresenta como uma entidade independente, mas como fruto do vínculo entre um objeto e um sentimento, uma emoção. Os sentimentos religiosos são "estados concretos de espírito, feitos de um sentimento mais um tipo específico de objeto". E assim como não existem sentimentos religiosos independentes, também não existem objetos religiosos nem atos religiosos intrinsecamente. Isso permite posicionar o sentimento religioso em campo mais próximo das experiências cotidianas comuns.

O sentimento característico da experiência religiosa é uma "adição absoluta à esfera de vida do indivíduo", concedendo a ele força e poder para enfrentar as vicissitudes da vida. Além disso, permite ao indivíduo lidar com as questões morais de seu tempo e contexto, pois a força proveniente da experiência religiosa contribui para que ele vá além das "regiões em que a moral propriamente dita, na melhor das hipóteses, só pode inclinar a cabeça e aquiescer”. O sentimento religioso impulsiona atitudes que são amparadas nas experiências e ideias do passado e, ao mesmo tempo, em ações criativas e inovadoras no presente (JAMES, 1995, p. 41). Por isso, James (idem, p. 42-43) afirma que o exame da experiência religiosa deve testar a sua potencialidade para facilitar e felicitar "o que, de qualquer maneira, é necessário". Se os resultados confirmarem essa característica, estará provada, no âmbito da experiência e no espectro maior das proposições pragmáticas jamesianas, a sua "função", ou seja, algo "que nenhuma outra porção de nossa natureza pode cumprir com tanto sucesso". ${ }^{13}$

Na obra Pragmatismo, encontramos a afirmação de que, do mesmo modo como sentimos por intermédio de nossos órgãos sensoriais, nossas concepções e ideais podem oferecer sentido e significados, se tiverem algum uso, alguma função, "e o significado será verdadeiro se o uso se harmonizar bem com outras utilidades na vida". James

\footnotetext{
${ }^{13}$ Nas conferências XIV e XV de Variedades, James caracteriza a experiência religiosa como uma função, expondo ideias que podem ser compreendidas com base em concepções darwinianas.
} 
(1978, p. 131) alerta, contudo, que a noção de uso, no campo da religiosidade, nem sempre pode ser entendida exclusivamente por meio de uma chave científica, mas, preferencialmente, em termos "emocionais e espirituais como um todo".

James (1995, p. 36) reconhece que esse campo da experiência não possui uma “única concepção que possa ser traçada com nitidez. A pretensão (...) de ser rigorosamente 'científico' ou 'exato' (...) serviria apenas para marcar a falha de nossa compreensão" do tema em pauta. Niebuhr (1998, p. 223) entende que filósofo “distingue múltiplos sinais da religião, mantendo sempre em mente que as diferenças entre os fenômenos religiosos e não religiosos são vagas e variáveis”. Esse mesmo autor considera "flexível" a definição jamesiana de religião, que flutua "entre especificações de sentimentos, atos e experiências, de um lado, e especificações do que pode ser considerado 'o divino', de outro; ou seja, entre polos 'subjetivos' e 'objetivos' ou 'intencionais' da experiência religiosa" (idem, p. 224)

Ainda segundo Niebuhr (2002, p. 224), os polos objetivos abrangem a descrição do divino, seu aspecto ativo e sua característica de semelhança com Deus, embora não seja necessariamente postulada a existência de um Deus. A caracterização jamesiana do divino consiste em afirmar que os deuses são coisas que nos envolvem, formulação esta que realiza uma objetivação da dimensão divina. No polo subjetivo estão as formas pelas quais os indivíduos respondem ao divino. As "respostas religiosas excedem a estrutura moral da mente"; moralidade "implica esforço volitivo", ao passo que "no estado religioso da mente" impera a complacência, dissolvendo-se qualquer vaidade. Outro aspecto relevante dessas respostas é a felicidade, um sentimento que não reconhece o mal mundano como uma espécie de penitência, mas como algo superado interiormente. Miedema (2002, p. 74) lembra que devemos tomar o cuidado de não vincular as proposições religiosas jamesianas "unicamente com os domínios subjetivo e privado da experiência pessoal", uma vez que elas possuem "algumas implicações para o domínio público".

\section{O sentimento de realidade}

Como se pode notar, a conceituação proposta por James é sustentada por uma fina trama de elementos cujas implicações abrangem diferentes âmbitos - o da formação da personalidade, o da conduta e o das relações sociais -, o que dificulta sobremaneira a tarefa de propor uma definição fixa para o tipo de experiência por ele investigado. Sua opção por trabalhar com relatos de gênios e precursores religiosos serviu justamente 
para fugir de confusões e mal-entendidos sobre as peculiaridades da experiência religiosa, tanto no que diz respeito à sua dimensão objetiva, quanto nos aspectos subjetivos que o envolvem, relacionados às atividades operadas pelos indivíduos. Nos relatos, diz James (1995, p. 36), "divindade do objeto e a solenidade da reação são tão bem marcadas que não dão margem à dúvida"; nesses casos, "o espírito religioso é inequívoco e extremo".

Todas as nossas ações morais, práticas, emocionais e religiosas que constituem a experiência religiosa estão vinculadas aos "objetos" de nossa consciência, as "coisas que acreditamos existirem, seja real, seja idealmente, junto de nós", coisas que estão "presentes aos nossos sentidos, ou (...) presentes apenas ao nosso pensamento"; são representadas como abstrações e ocupam o centro da questão, que é o fato de provocarem "em nós uma reação" (JAMES, 1995, p. 44). James (idem, p. 45) refere-se à nossa capacidade de sentir coisas que não existem no mundo exterior, como os pensamentos, as ideias, a imaginação etc., abstrações que não raramente ocasionam reações, atitudes, o que constitui um dado psicológico; as abstrações são nossas construções e significações acerca do mundo sensível, habitando nosso campo da consciência.

"A determinabilidade absoluta de nossa mente por abstrações é um dos fatos cardeais da nossa constituição humana. (...) elas são (...) tão reais no reino que habitam quanto as coisas mutáveis dos sentidos o são no reino do espaço”. James (1995, p. 46) chama essas abstrações de nossos "objetos" da consciência, e procura justificar essa denominação com base em experiências realizadas por meio da indução resultante do processo de hipnose. Esses experimentos sustentam a noção de "sentido de realidade", a qual descreve o fato de os "objetos" da consciência irem além de ideias, pensamentos, imaginação ou mesmo de alguma concepção abstrata elaborada pelo intelecto, tornandose passíveis de serem sentidos diretamente, como no mundo fenomênico (idem, p. 47). ${ }^{14}$ Embora pareça estranho a quem não está familiarizado com os desenvolvimentos da psicologia daquela época, James (1995, p. 48) afirma estar lidando com "um tipo de fato natural bem marcado"; o "sentido da realidade pode ser algo mais parecido com uma sensação do que com uma operação intelectual” (idem, p. 50). Niebuhr (1998, p. 221) explica que o "sentido da realidade" jamesiano é proveniente de “objetos abstratos (como a alma, Deus, a imortalidade), sendo, porém, algo mais difuso

\footnotetext{
${ }^{14} \mathrm{Na}$ conferência III de Variedades, James apresenta vários exemplos do "sentido de realidade".
} 
do que os nossos sentidos no mundo fenomênico". Mesmo sendo definido de modo um tanto vago, Niebuhr acredita tratar-se de "um significado definido em nossa prática".

Considerando as dimensões metafísicas e religiosas, James (1995, p. 56), entende que o racionalismo, orientado pelo raciocínio lógico e dedutivo, elaborado em bases definíveis, apenas se torna irresistível "quando nossos sentimentos indefiníveis da realidade já foram impressionados em favor da mesma conclusão". O filósofo se ampara na observação do comportamento e da vida mental dos homens, para dizer que aquilo que se justifica "pelo racionalismo é relativamente superficial"; embora possua "loquacidade", não possui significância, caso as suas intuições se oponham às suas conclusões. James $(1899$, p. 56) acredita que as intuições são oriundas de "um nível mais profundo (...) do que o nível loquaz habitado pelo racionalismo”.

Portanto, James (1899, p. 56) não concebe oposição entre sentimento e razão, uma vez que "nossas intuições e nossa razão trabalham juntas". Cabe ressalvar, contudo, que essas assertivas de James são desenvolvidas considerando a atuação do racionalismo no campo da religião. "A inferioridade do nível racionalístico é tão manifesta quando o racionalismo argui em favor da religião" quanto "quando argui contra ela". James (1995, p. 45) sintetiza o poder exercido pelo sentimento de realidade sobre as pessoas defendendo que uma de suas características é a de se conectar "de maneira tão robusta ao nosso objeto de crença que toda nossa vida é polarizada de fio a pavio, por assim dizer, pelo sentido que damos à existência da coisa em que acreditamos".

\section{Os componentes da experiência religiosa}

James articula um discurso filosófico com o propósito de trabalhar certos conhecimentos pertencentes à esfera da psicologia, visando elucidar os seus significados para a vida humana. Sua discussão envolve o exame das correntes religiosas e espirituais de sua época, como a que prescreve a cura espiritual, para esclarecer as relações dessas doutrinas com algumas peculiaridades psicológicas da consciência, as quais recebem o nome de "equilíbrio mental". Trata-se de um equilíbrio sistemático com vistas ao otimismo, que é alcançado pelo hábito e constitui importante auxílio na composição da religiosidade como uma função para o ser humano (JAMES, 1995, p. $65)$. 


\section{O ambiente e o temperamento individual}

James (1995, p. 65) distingue entre as pessoas que desenvolvem facilmente um caráter de otimismo e aquelas que passam por um processo que demanda esforço, sistematização e deliberação. Ambas buscam equilíbrio, mas o sentimento dos otimistas se instala de modo involuntário, decorrente da excitação pela alegria que surge de modo simples, "congênito", sem esforço ao simples contato com as coisas. "Em sua variedade sistemática, é um modo abstrato de conceber as coisas como boas". O indivíduo seleciona um aspecto da sistematização que caracteriza por ser sua essência, marginalizando os demais. "O equilíbrio mental sistemático, concebendo o bem como o aspecto essencial e universal do ser, exclui deliberadamente o mal do seu campo de visão" (idem, p. 66).

Esse processo de sistematização pode ser compreendido pelo exemplo da felicidade apresentado por James (1995, p. 65). A felicidade, “como todos os outros estados emocionais, é cega e insensível aos fatos contrários dados a ela como arma instintiva para se proteger de uma possível perturbação”. Quando um indivíduo está sob domínio dessa emoção, "a ideia do mal já não pode lograr o sentido de realidade”. A essa atitude James chama de uma "política religiosa deliberada, ou parti pris".

A busca por equilíbrio é basilar na experiência religiosa, uma vez que o homem possui “dupla natureza", está vinculado a "duas esferas do pensamento, uma superficial e outra profunda", podendo "aprender a viver mais habitualmente" em qualquer uma delas (JAMES, 1995, p. 70). Essa ideia pode ser compreendida no registro da teoria da evolução de Charles Darwin, segundo a qual algumas doutrinas religiosas podem contribuir para a adaptação social do indivíduo e, portanto, para o progresso da sociedade. Garrison (2002, p. 31) analisa essa dimensão adaptativa da vida religiosa, afirmando que toda criatura viva "que deseja sobreviver e crescer deve estabelecer relações com aspectos do mundo externo à sua existência, que são, não obstante, internos ao seu funcionamento".

James (1995, p. 79) destaca que a experiência religiosa sofre a influência das circunstâncias, do contexto que envolve o indivíduo: "A influência sugestiva do ambiente desempenha parte enorme em toda educação espiritual”, diz o filósofo. Para compreender essa formulação, podemos recorrer à explicação que se encontra no livro $A$ vontade de crer, de 1896, no qual James (2001, p. 9) explica que uma "hipótese viva é a que aparece como uma possibilidade real para a pessoa a quem é proposta"; o "caráter vivo ou morto de uma hipótese não é uma propriedade intrínseca, mas está relacionado 
ao pensador individual”, o que remete ao seu contexto geográfico e social. Entende-se, assim, por que, em certos lugares, uma religião tem mais adeptos e se mostra mais persuasiva do que outras (idem, p. 10).

O equilíbrio mental requer, ainda, a contribuição de outro fator relevante, o temperamento, que varia de um indivíduo a outro. Os indivíduos mentalmente equilibrados, tanto por determinação congênita quanto por ação voluntária, possuem disposições alegres. Os melancólicos não possuem essa disposição, e o esforço para obter segurança e felicidade é, para eles, maior e mais marcado, porque tais indivíduos elaboram sistemas abstratos mais complexos que incluem, simbolicamente, todo o mal do mundo fenomênico. Esse "modo de sentir, sendo o mais extremado, é o mais instrutivo para o nosso estudo", diz James (1995, p. 93).

Os melancólicos percebem o mundo como algo confuso e alienado; o mundo, para eles, é algo "remoto, estranho, sinistro, fantástico" (JAMES, p. 103). Essa percepção é potencialmente um estímulo para o intelecto, podendo resultar em um "doloroso e opressivo" questionamento e esforço visando atingir "alívio filosófico" (idem, p. 102). Esse alívio se processa por meio de "um esforço angustiado de indagação, uma atividade teórica insaciável"; quando tenta desesperadamente "estabelecer relações certas com a matéria, o paciente é frequentemente levado para o que se torna para ele uma solução religiosa satisfatória" (idem, p. 103). James descreve esse alívio filosófico ou solução religiosa satisfatória como uma combinação indistinguível entre "os fatos físicos e os valores emocionais", uma "mudança operada no sujeito" que transfigura a "face da natureza a seus olhos".

A intensidade e a complexidade são os parâmetros com os quais James (1995, p. 109) distingue o modo mentalmente equilibrado de atingir conforto e equilíbrio, de um lado, do modo como procedem os melancólicos, ou de "mente mórbida", de outro lado. A estes, "o equilíbrio mental puro e simples afigura-se indizivelmente cego e superficial". Aos equilibrados, "o modo da alma enferma se apresenta desvirilizada e doentia".

"O método de desviar nossa atenção do mal e viver simplesmente em plena luz do bem é esplêndido enquanto funciona. Funcionará com muitas pessoas; funcionará de modo muito mais geral do que a maioria dentre nós está preparada para supor”, diz James (1995, p. 109-110). A questão é que o otimismo e a felicidade atingidos pelos mentalmente equilibrados os impede de construir uma experiência capaz de integrar os elementos negativos, ou maus, muito embora não se possa censurar sua "solução 
religiosa" no interior da "esfera da sua operação bem-sucedida" (idem, p. 110). O problema está em que esse tipo de solução pode se desarranjar a ponto de conduzir à melancolia. E mesmo que isso não ocorra, "não há dúvida de que o equilíbrio mental é inadequado como doutrina filosófica, porque os fatos maus, que ele se recusa positivamente a tomar em consideração, constituem uma porção genuína da realidade".

Assim, James (1995, p. 110) explica que os processos de sistematização e indagação que ocorrem nos indivíduos melancólicos sejam "a melhor chave para o significado da vida e, possivelmente, os únicos abridores dos nossos olhos para os níveis mais profundos da verdade". Pode-se entender, portanto, que James vê a experiência religiosa não como uma fuga da realidade, um distanciamento, mas, pelo contrário, como uma apreensão mais profunda do meio vivido, tanto no aspecto físico quanto no social e moral. A experiência religiosa é um meio pelo qual o indivíduo se apropria das complexidades do ambiente, de modo muitas vezes poético ou musical (idem, p. 292).

O eixo da questão reside nas relações construídas entre o indivíduo e o ambiente, abarcando a moral, a linguagem, os valores, os símbolos etc., tudo o que é determinante para o modo como o indivíduo sistematizará a sua experiência religiosa. Essa dinâmica promotora da inter-relação entre o indivíduo e o meio é vista por Garrison (2002) como uma dimensão de extrema relevância para a experiência religiosa, pois consiste em um processo de ampliação dos horizontes por meio de um exercício criativo de interação e produção de significados. O alargamento da significação e dos valores que deriva do desenvolvimento de "experiências potencialmente religiosas" ocorre por intermédio de ações morais, inteligentes e criativas. Garrison (idem, p. 28) vê as experiências religiosas como um movimento que fazemos para "assegurar melhores relações com os outros em nosso meio, especialmente nosso meio social", o que as qualifica como experiências potencialmente geradoras de um "relacionamento mais íntimo com a existência em geral".

\section{A conduta e a unificação de sentimentos}

É possível identificar meios práticos capazes de tornar mais íntimas as relações do indivíduo com o meio e com outros indivíduos. Certas alterações de comportamento podem resultar em elevação espiritual e ampliação dos significados da existência, como acontece no movimento da cura psíquica, doutrina que prega a higiene espiritual a partir da conduta, nos mesmos moldes da doutrina do relaxamento apresentada em Talks, 
como vimos no primeiro capítulo deste trabalho; pode-se alcançar o controle das paixões por intermédio do controle da formação de hábitos, visando a novas condutas e, assim, ao progresso social.

Pela conduta, podemos controlar sentimentos que nos tornam mais fechados às relações interpessoais, como o egoísmo e a disposição para machucar os outros, como diz Garrison (2002, p. 28). A busca por uma convivência criativa e inteligente em meio à diversidade constitui "uma experiência potencialmente religiosa, ou pelo menos espiritual" com implicações marcantes, uma vez que evidencia o poder de nossas ações para impactar, mesmo que indiretamente, os nossos sentimentos. Certos "sentimentos necessários" - como a humildade, a ausência de egoísmo e menor disposição para prejudicar os outros - podem nos tornar "mais abertos, não menos". Para Garrison, a resposta adequada para problemas e angústias da vida deve ser um "desejo por auxílio e compartilhamento", para obtermos "relações mais íntimas, para atingirmos os outros, fazer conexões com eles e incluí-los em nossas vidas". Assim, podemos alcançar "o que há de imortalidade em nossas relações, especialmente em nossas crianças" - afirmação que coloca em primeiro plano a educação.

Desse modo, a noção jamesiana de experiência religiosa envolve um complexo sistema com evidente dimensão moral, associando processos de criação e inclusão a termos como alma, Deus e imortalidade, na esfera ampla de conexões criativas e inteligentes. Acontece que, segundo James (1995, p. 113), os melancólicos são segregados desse universo, pois possuem um "temperamento congênito" que se caracteriza por uma "constituição moral e intelectual incompletamente unificada".

O processo para superar esse quadro de incompletude dos melancólicos pode se dar por meio de uma "alteração dos sentimentos ou dos poderes de ação; pode chegar diante de novas visões intelectuais ou experiências que (...) designaremos como “místicas"” (JAMES, 1995, p. 117). O resultado da unificação será um alívio, cuja forma mais extrema é observada na experiência religiosa, mas, por constituir um "processo psicológico geral", não precisa assumir necessariamente a "forma religiosa". Quando ocorre no âmbito do universo religioso, suas características - "a firmeza, a estabilidade e o equilíbrio que se seguem a um período de tempestade, tensão e incoerência" - são mais acentuadas. É por esse motivo, por apresentar a forma mais extrema, que James optou por estudá-lo para elaborar o conceito de experiência religiosa. 
No processo de unificação, não basta o intelecto, sendo determinantes a presença da emoção e do sentimento. As energias intelectuais devem ser combinadas com "o sentimento ou a fé irracionais" (JAMES, 1995, p. 123). Segundo Garrison (2002, p. 32), não se trata de uma fé imbuída da "atitude quietista" que qualifica qualquer evento como "vontade de Deus". Pelo contrário, a fá jamesiana é uma "fé criativa", não "passiva", mas "ativa", dedicada a "transformar o mundo completamente". A combinação de elementos múltiplos, intelectuais e emocionais, resultará na unificação do eu por meio da deliberação.

\section{A experiência de conversão}

Para explicar o processo de unificação do eu, James discorre sobre a “conversão", fenômeno que se pode compreender com base nas noções jamesianas de "associação de ideias" e "interesse". Nossas "ideias, metas e objetivos", diz James (1995, p. 128), compõem "diversos grupos e sistemas internos, relativamente independentes uns dos outros", mas agrupados por meio do processo de associação, pelo qual "certo tipo de excitação interessada" reúne "certo grupo de ideias a ela subordinadas como suas associadas".

Sempre "que uma das metas se torna tão estável que expulsa definitivamente suas rivais anteriores da vida do indivíduo", dizemos que ocorreu uma "transformação" (JAMES, 1995, p. 129). Do ponto de vista da psicologia, é assim que se descreve o processo de divisão do eu. "Um modo menos completo é a coexistência simultânea de dois ou mais grupos diferentes de metas", uma delas detendo "o direito de passagem, enquanto as outras são meros desejos piedosos e, praticamente, nunca chegam a coisa alguma".

As associações são mobilizadas no interior do fluxo da consciência - conceito que vimos em Talks, no capítulo anterior deste trabalho -, indo de áreas mais periféricas para áreas mais centrais, e vice-versa, sendo estimuladas pela "excitação emocional" (JAMES, 1995, p. 129). Todos sabemos que alguns sentimentos - "o amor, o ciúme, a culpa, o medo, o remorso ou a raiva" - operam de maneira súbita e explosiva, podendo apoderar-se inteiramente de nós. As emoções que nos assaltam com essa intensidade, passionalmente, "raramente deixam as coisas como as encontram" (idem, p. 131).

Dizer que uma pessoa está convertida significa afirmar que "as ideias religiosas, anteriormente periféricas em sua consciência, assumem agora um lugar central, e as metas religiosas formam o centro habitual da sua energia”. Em outras palavras, a 
conversão é o processo que leva certas ideias a ocuparem espaço privilegiado no referido centro de energia, tornando-se algo que mobiliza o indivíduo, algo pelo que ele trabalha e em que ele se consagra (JAMES, 1995, p. 130).

James (1995, p. 131) afirma que a mente é um "sistema de ideias, cada qual com o estímulo que desperta, e com tendências impulsivas e inibidoras, que mutuamente contrastam ou se reforçam". Esse sistema pode estabelecer novos arranjos e orientar-se por outras tendências, segundo o "curso da experiência". Assim, um "sistema mental pode ser minado ou enfraquecido por essa ação intersticial" no decorrer da experiência, porém consegue manter-se "por força do hábito".

O hábito, nesse caso, deriva da forma como o indivíduo foi instruído, sendo, portanto, o único recurso para a constituição de metas por meio da associação de ideias (JAMES, 1995, p. 132). Esse mecanismo é resultante da "sugestão" e da "imitação", mas todo fenômeno habitual e imitativo possui uma origem, uma criação original, que são os fenômenos que James (idem, p. 132) qualifica como "experiência de primeira mão", experiências que possuem "maior originalidade" e são dotadas da capacidade de transgredir o que é estabelecido pelo hábito.

Para explicar essas experiências originais que, aliás, constituem os modelos precursores das religiões, James (1995, p. 151) discorre sobre o que a psicologia denomina regiões "extramarginais", formadas por "lembranças, pensamentos e sentimentos", por "fatos conscientes" cuja presença é revelada por meio de "sinais inequívocos". A atividade dessa região tem por consequência a sujeição dos "campos ordinários da consciência" a algo de que o sujeito não tem conhecimento e que "assume para ele a forma de inexplicáveis impulsos para agir, inibições, ideias obsessivas e até alucinações da vista ou da audição". Assim, "energias procedentes das partes subliminais da mente" irrompem na "consciência ordinária".

Nas pessoas que possuem um campo da consciência mais amplo, com mais associações e um estoque maior de ideias, a tendência é que ocorra a conversão súbita, como consequência da incursão de elementos extramarginais no campo da consciência primária. Segundo James (1995, p. 153), trata-se de sujeitos dotados de "ampla região em que o trabalho mental prossegue subliminalmente, e do qual podem irromper experiência invasivas, que perturbam de repente o equilíbrio da consciência primária”. Quando os campos são mais estreitos, o processo é gradual, a atividade subliminal é menos intensa e os elementos provenientes adentram a consciência primária de modo mais lento. 


\section{A experiência religiosa no âmbito da cultura}

Childs (1959, p. 291) analisa que o Pragmatismo considera o homem "tanto uma criatura da civilização quanto uma criatura biológica", cujos "costumes, instituições e tradições" variam de um a outro grupo social, variando igualmente o modo como são engendrados os hábitos, os gostos e as atitudes; os "objetos de lealdade e devoção" resultam de construções sociais que inscrevem nas mentes individuais os "significados intelectuais e morais" relevantes para a vida. O método pragmático, cuja busca não é pela origem dos fenômenos, mas pela investigação de suas consequências, leva James a estudar os efeitos da experiência religiosa no indivíduo, focalizando sua atitude ética, isto é, sua conduta em sociedade, mediante os resultados da conversão.

Qualquer que seja a forma da experiência de conversão vivenciada, o fato é que o seu processamento revela ao ser humano "o ponto culminante da sua capacidade espiritual” (JAMES, 1995, p. 165). É com essa reflexão que podemos ingressar James no terreno mais amplo da cultura, considerando ser a cultura o contexto em que são produzidas as emoções e as paixões, as quais, por sua vez, respondem pela formação do caráter e da conduta individuais. $\mathrm{O}$ vasto conjunto de posicionamentos, preferências, atitudes e sentimentos não se efetiva diretamente, carecendo sempre de algum filtro que o regule. A ação dos indivíduos não se institui de modo unilateral pelas emoções, acontecendo também por intermédio de um processo de deliberação em que os impulsos e as inibições são tratados com razoabilidade.

\section{A santidade}

Assim, "nossa atitude moral e prática (...) é sempre resultante de dois conjuntos de forças dentro de nós, impulsos que nos empurram numa direção e obstruções e inibições que nos retêm" (JAMES, 1995, p. 168). Nesse processo conflitante, diz James (idem, p. 169), o indivíduo pode experimentar várias discordâncias, mas há sempre um ápice que, ao ser atingido, conclui a "composição do caráter enérgico" que possui “poder particularmente destrutivo sobre as inibições”. É certo dizer que as pessoas possuem caráter, conduta e temperamento diferentes, mas os processos que os estabelecem são interpretados pela psicologia segundo esse modo comum.

Quando as paixões estão relacionadas com características do universo religioso, é possível observar o engendramento de práticas, condutas e moral. James (1995, p. 174) dá o nome de "santidade" aos frutos maduros da experiência religiosa, explicando 
que o "caráter santo é aquele em que as emoções espirituais são o centro habitual da energia pessoal"; as religiões, embora difiram entre si, coincidem na atribuição dos qualificativos do que se pode denominar "santidade universal".

Niebuhr (1998, p. 230) esclarece que, na concepção jamesiana, santidade é o "resultado ideal, embora incerto, da conversão". O caráter santo que se forma no indivíduo supera as suas inibições por meio de uma emoção que se forja no interior de um contexto físico e mental, composto por elementos associados àquilo que se considera divino. Durkheim (2004, p. 148-149) entende que santidade envolve um modo de vida que comporta um "estado ideal" de virtudes e, consequentemente, uma conduta que se pode caracterizar como santa.

No Quadro I, a seguir, apresentamos os componentes da imagem universal da santidade a que se refere James. Na primeira coluna desse Quadro, estão os elementos que pertencem ao centro habitual de energia pessoal, relativos aos objetos da consciência, ou abstrações, que ocupam as porções centrais de nossa consciência, constituindo nosso caráter. $\mathrm{Na}$ segunda coluna estão registradas as condutas que tais arranjos da consciência podem engendrar. James (1995, p. 214) alerta para o fato de que cada um dos componentes da santidade está sujeito à corrupção pelo exagero; todas as condutas podem se tornar prejudiciais ao indivíduo, se empreendidas sem comedimento, sem moderação.

Quadro I - Os componentes da santidade, segundo William James

\begin{tabular}{|l|l|}
\hline \multicolumn{1}{|c|}{ Caráter } & \multicolumn{1}{|c|}{ Conduta } \\
\hline $\begin{array}{l}\text { Centro habitual da energia pessoal } \\
\text { mais ampla do que a dos interesses } \\
\text { egoístas deste mundo; e uma convicção, } \\
\text { não meramente intelectual, mas, por assim } \\
\text { dizer, sensível, da existência de um Poder } \\
\text { Ideal". }\end{array}$ & $\begin{array}{l}\text { "Ascetismo" - Renúncia de si com vistas a } \\
\text { vonstituir hábitos novos que priorizem } \\
\text { romper morais e éticos, no intuito de } \\
\text { de hábitos rotineiros. Pode conduzir a } \\
\text { outras condutas como "castidade", } \\
\text { "obediência" "pobreza". }\end{array}$ \\
\hline $\begin{array}{l}\text { "Um sentido da continuidade amistosa do } \\
\text { poder ideal com a nossa vida, e um } \\
\text { abandono solícito ao seu controle". }\end{array}$ & $\begin{array}{l}\text { "Força da Alma" - "O sentido do } \\
\text { alargamento da vida" que suprime } \\
\text { "inibições pessoais, comumente } \\
\text { onipotentes", tornando-as "insignificantes } \\
\text { demais para serem notadas". Permite que } \\
\text { surjam "novas extensões de paciência e } \\
\text { fortaleza". }\end{array}$ \\
\hline
\end{tabular}




\begin{tabular}{|c|c|}
\hline $\begin{array}{l}\text { "Uma alegria e uma liberdade imensas, à } \\
\text { proporção que os contornos da } \\
\text { individualidade limitadora se derretem". }\end{array}$ & $\begin{array}{l}\text { "Pureza" - Eminência da "sensibilidade às } \\
\text { discórdias espirituais", conduzindo a uma } \\
\text { vida que afasta "elementos brutais e } \\
\text { sensuais". Relaciona-se ao corpo e ao } \\
\text { espírito. Cuidado com a saúde e prática de } \\
\text { uma higiene mental reflexiva que promova } \\
\text { maior conhecimento do indivíduo sobre si } \\
\text { mesmo. }\end{array}$ \\
\hline $\begin{array}{l}\text { "Uma transferência do centro emocional } \\
\text { para afeições amantes e harmoniosas". }\end{array}$ & $\begin{array}{l}\text { "Caridade" - Alteridade, empatia, } \\
\text { "aumento da caridade, ternura pelos } \\
\text { semelhantes". Percepção de todos como } \\
\text { iguais e dignos de respeito, sob a } \\
\text { orientação de princípios pluralistas e de } \\
\text { inclusão. }\end{array}$ \\
\hline & $\begin{array}{l}\text { "Mistério da democracia" - "Esse } \\
\text { sentimento tende a anular a ganância } \\
\text { costumeira dos homens". Rejeitam-se } \\
\text { títulos e privilégios. É a humanidade se } \\
\text { recusando a ter o que outros não têm. }\end{array}$ \\
\hline
\end{tabular}

Fonte: As variedades da experiência religiosa (JAMES, 1995, p. 175-176)

Para avaliar a constituição mental e as condutas individuais, James (1995, p. 207) recusa a adoção de um sistema a priori, preferindo examinar cada um dos elementos com base naquilo que produzem, para só então estabelecer seus valores, sem grande sistematização, considerando apenas seus aspectos gerais e suas relações a longo prazo. Deve ser assim porque não é possível dividir o homem em corpo e espírito, nem dissociar suas emoções e sua moral de sua conduta; deve-se observar a complexidade que é tecida pela confluência entre os componentes. No que tange à sociedade, deve-se observar o caráter acumulativo de conhecimentos, para que se possa verificar se determinada religião ocasiona benefícios à vida social.

\section{Uma passagem pela história}

James (1995, p. 208) reflete sobre a evolução moral experimentada no âmbito religioso pelas civilizações, dizendo que as necessidades do ser humano quanto à religiosidade mudaram de acordo com os avanços e novos "ajustamentos sociais" que se realizaram juntamente com o desenvolvimento da ciência. Tais transformações levaram o indivíduo a demandar uma relação com a religiosidade que não fosse antagônica aos 
progressos científicos, econômicos, sociais e políticos. Atualmente, se uma divindade exigisse "sacrifícios de sangue" para ser aceita, certamente não seria levada a sério.

A divindade testemunhada por "profetas, videntes e devotos" era algo de valor para eles, "pessoalmente", mas assim que esse valor começava a declinar, instalava-se o conflito com "ideais humanos indispensáveis" e, em consequência, "a divindade era desacreditada", ou "descurada e esquecida" (JAMES, 1995, 208). Com isso fica demonstrada a presença da "voz da experiência humana dentro de nós, julgando e condenando todos os deuses que interceptam o caminho ao longo do qual ela sente estar avançando" (JAMES, 1995, p. 209). ${ }^{15}$

O avanço a que se refere o filósofo parece necessitar da atuação de um homem com qualidades especiais, que rejeita o isolamento, que busca a integração com seus pares e reconhece a provisoriedade do mundo: "O mais sábio dos críticos é um ser variável, sujeito sempre a ver melhor o amanhã, e cônscio de estar na verdade somente enquanto se trata de uma verdade provisória, 'atualizada' e 'em conjunto'”. Quando profetas e poetas vivem a religiosidade, eles se deparam com "horizontes mais amplos da verdade", assumindo a diversidade da existência, e por isso devemos "abrir os olhos para vê-los, desacorrentados de nossas convicções anteriores” (JAMES, 1995 p. 210).

$\mathrm{Na}$ conceituação de James, nota-se o relevante papel da santidade na articulação de doutrinas e igrejas, mas também no engendramento de utopias capazes de mobilizar os indivíduos, seja no âmbito teórico das ciências humanas, seja no âmbito profético da religião, como também na literatura ou na poesia. As expressões resultantes da experiência religiosa possuem uma linguagem que ultrapassa o tempo e o espaço, expressando um caráter inovador e questionador que, muitas vezes, põe em risco aqueles que as professam. Orientado pelo método empírico e pelo bom senso, James (1995, p. 235) afirma que a experiência religiosa assume "lugar elevado na história", sendo "indispensável para o bem-estar do mundo". Os "grandes santos" obtêm sucesso imediatamente; "os menores, na pior das hipóteses, são arautos e precursores", fermentadores de uma "ordem profana melhor". Seguindo os "métodos da filosofia empírica", cada pessoa deve descobrir por si mesma "o tipo de religião e a dose de santidade que melhor se harmoniza com o que acredita serem seus poderes".

\footnotetext{
15 James (1995, p. 210) parece aplicar às religiões a concepção evolucionária de Darwin, ao dizer as primeiras religiões foram suplantadas quando "violaram outras necessidades com demasiado vigor, ou quando sobrevieram outras fés que serviam melhor às mesmas necessidades".
} 


\section{Os estados místicos de consciência}

Por considerar a "experiência pessoal como tema exclusivo do nosso estudo", diz James (1995, p. 237), devemos compreender que a "experiência religiosa pessoal tem sua raiz e seu centro em estados místicos de consciência”. Johnson (2002, p. 155) destaca que essa concepção jamesiana permite atribuir um significado mais rico às experiências comuns da vida cotidiana, uma vez que sua peculiaridade reside em não conceber o método científico como adversário de uma "visão de mundo místico/religiosa".

Sendo os estados místicos o arranjo específico em que a experiência religiosa tem mais possibilidade de alcançar a plenitude, James (1995, p. 237-238) os organiza em quatro tipos que compõem o que denomina "grupo místico" - Inefabilidade, Qualidade Noética, Transitoriedade e Passividade. Preponderam os dois primeiros, que são suficientes para permitir chamar de místico qualquer estado da consciência. Inefabilidade diz respeito a paixões, sentimentos, cujos conteúdos não podem ser expressos por meio de palavras, sendo desprovidos de encadeamento lógico; seu valor só pode ser comunicado por intermédio de experiências em comum. ${ }^{16}$ Qualidade Noética refere-se a "estados de conhecimento, estados de visão interior", dirigidos às "profundezas da verdade não sondadas pelo intelecto discursivo"; seu valor consiste em abrir caminho para algo inovador e rico em "significado e importância".

A Transitoriedade e a Passividade, embora encontradas com certa frequência, não são determinantes para os estados místicos da consciência. A primeira caracteriza a brevidade da experiência, que varia de alguns minutos a poucas horas, em tal rapidez que inviabiliza sua clara reprodução; sua ocorrência promove o "contínuo enriquecimento" na vida interior daqueles que a experimentam. A Passividade, por fim, realça a impressão de que a "própria vontade está adormecida" e conduzida por uma "força superior"; ela ocorre no "discurso profético", na "escrita automática" ou no "transe mediúnico", sendo tão intensa que acaba não sendo memorizada, embora James observe que nos estados místicos "subsiste sempre alguma lembrança do seu conteúdo e um sentido profundo de sua importância”. Na Passividade, nota-se um esforço do indivíduo em estimular a conexão com o que ele considera divino: a "fixação da

\footnotetext{
${ }^{16}$ Niebuhr (1998, p. 232) diz que inefável, em James, significa uma expressão não conceitual, um modo diferente de argumentação caracterizado pela eloquência verbal, como se nota nos registros de Santa Teresa apresentados em Variedades.
} 
atenção, a execução de certos gestos corporais, ou outras maneiras prescritas pelos manuais de misticismo" (JAMES, 1995, p. 238).

Nas experiências místicas há uma "significação mais profunda" que não é percebida unicamente em sistemas racionalmente elaborados, mas também nas expressões artísticas, como a música, a poesia, a literatura etc. "Palavras singelas, conjunções de palavras, efeitos de luz na terra e no mar, odores e sons musicais", tudo pode provocar uma experiência desse tipo "quando a mente está corretamente afinada". (JAMES, 1995, p. 239). Aqueles que experimentam estados místicos falam da "unidade do homem com Deus" em discursos que "precedem as línguas" e não envelhecem (idem, p. 261). Nessas expressões encontramos a prova de que "a verdade mística não é a fala conceitual”, mas a música e a poesia. "Muitas escrituras místicas são, com efeito, pouco mais do que composições musicais" (idem, p. 262).

James (idem, p. 249) analisa que as experiências místicas podem "determinar atitudes", ainda que não veiculem fórmulas; podem "abrir uma região", mesmo sem oferecer um mapa. Elas integram diversos elementos, conjugando a estrutura da consciência do indivíduo e o contexto do meio social e físico em que a pessoa está inserida. Trata-se de uma experiência que pode ser compreendida como "superadição de uma função, tão distinta de qualquer outra possuída pelo homem comum”. James (idem, p. 259) acredita que a experiência mística torna "a alma mais enérgica em direções favorecidas pela inspiração. Mas isso só pode ser considerado vantagem se a inspiração for verdadeira. Se a inspiração for errônea, a energia será correspondentemente mais equivocada e ilegítima".

Para James (idem, p. 261), essa forma de experiência manifesta "uma tendência teórica assaz distinta. É possível dar o resultado da maior parte dela em termos que apontam para direções filosóficas definidas". Seu efeito é sensivelmente percebido pelos que a sofrem, pois implica uma ampliação dos horizontes de significados do indivíduo, aumentando sua sensibilidade para as coisas do mundo. "Passamos da consciência ordinária para os estados místicos como passaríamos de um menos para um mais, de uma pequenez para uma vastidão, e ao mesmo tempo de uma agitação para um repouso". Ela é sentida como um estado unificador: "Nos estados místicos nos tornamos um com o Absoluto e nos tornamos conscientes da nossa unicidade".

A peculiaridade artística das expressões místicas, tal qual James as vê, podem ser compreendidas na interpretação de Johnson (2002, p. 155), que qualifica as proposições filosóficas jamesianas como capazes de articular "espiritualidade pré- 
moderna, racionalidade moderna e diversidade pós-moderna". James consegue unir tradição e valores culturais do ser humano com um trato filosófico conceitual sistemático e ainda configurar todos esses elementos em uma filosofia inclusiva, com vistas a compreender o impacto da dimensão religiosa sobre a vida humana sem necessariamente oferecer uma doutrina ou um sistema filosófico fechado.

James (1995, 263) considera que os estados místicos, "quando bem desenvolvidos, geralmente são, e têm o direito de serem autoridades absolutas sobre os indivíduos que os experimentam". A força com que a conduta é por eles orientada preenche apenas a dimensão do indivíduo que a sente e "não emana autoridade alguma que obrigue os que estão de fora a lhes aceitarem as revelações sem nenhuma crítica". Os estados místicos "quebram a autoridade da consciência não-mística ou racionalista, que se baseia apenas no intelecto e nos sentidos", evidenciando que esta "não passa de uma espécie de consciência"; abrem "a possibilidade de outras ordens de verdade, nas quais, na medida em que alguma coisa em nós responda vitalmente a elas, possamos continuar livremente a ter fé".

\section{As contribuições da investigação}

Em consonância com as diretrizes estabelecidas no início de Variedades e apresentadas na primeira seção deste capítulo, podemos fazer uma apreciação geral da proposta jamesiana utilizando as reflexões elaboradas pelo próprio ao término de sua investigação. Segundo James (1995, p. 269), o estudo realizado consistiu em "extrair das intimidades da experiência religiosa alguns fatos gerais capazes de serem definidos por meio de fórmulas a cujo respeito todos possam concordar". Trata-se de uma contribuição útil a uma filosofia que pretenda abandonar "a metafísica e a dedução pela crítica e pela indução", passando de uma teologia para uma ciência da religião (idem, p. 282).

Ao reconhecer que "o intelecto do homem sempre define o divino que ele sente de modos que se harmonizam com seus preconceitos intelectuais temporários", a filosofia "pode, por comparação, eliminar o local e o acidental dessas definições" e "remover incrustações históricas não só dos dogmas, mas também do culto". Estabelecendo ponderações acerca das “construções religiosas espontâneas com os resultados da ciência natural, a filosofia também elimina doutrinas que hoje se conhecem como cientificamente absurdas ou incongruentes" (JAMES, 1995, p. 282). 
Quando opta por filtrar "formulações que não valem nada", a filosofia abre caminho para tratar certos assuntos como "hipóteses, pondo-as à prova de todas as maneiras negativas ou positivas pelas quais as hipóteses sempre têm sido experimentadas". Por meio desse processo, a filosofia oferece "mediação entre diferentes crentes", estimulando o diálogo entre as diferenças e contribuindo para a instauração de um “consenso de opinião”. Isso será concretizado com sucesso quando a filosofia puder "discriminar os elementos comuns e essenciais dos elementos individuais e locais das crenças religiosas que estiver comparando" (JAMES, 1995, p. 282).

Situando sua investigação no registro da abordagem pragmatista, James esclarece que o estudo realizado não buscou elucidar a religiosidade, em si mesma, mas verificar as "utilidades da religião, suas utilidades para o indivíduo que a tem, e as utilidades do próprio indivíduo para o mundo", entendendo esses elementos como "os melhores critérios para julgar a verdade que está nela"; a verdade que está na religião só pode ser aquilatada pelo exame de seus efeitos na conduta das pessoas (JAMES, 1995, p. 284).

Um componente relevante para a conduta é a oração, que James (1995, p. 287) caracteriza como "religião em ato", o "ato vital pelo qual a mente inteira procura salvarse agarrada ao princípio do qual tira a sua vida". Não se trata de mero exercício de repetição de palavras, "senão o próprio movimento da alma, que se coloca numa relação de contato com misterioso poder cuja presença sente". O hábito de cultivar o "senso contínuo da nossa conexão com o poder que fez as coisas como elas são" pode nos tornar mais preparados para sentir essa conexão (idem, p. 293). A "face externa da natureza" não precisa ser alterada, mas altera os significados produzidos pelos indivíduos. James (idem, p. 300) diz que o universo espiritual a que o indivíduo tem acesso é fonte para a criação de significados para o mundo e para o estabelecimento de uma relação harmoniosa com o universo. Essa relação também acontece pela oração, que é, acima de tudo, uma ação, "um processo em que se faz realmente um trabalho, e em que a energia espiritual flui e produz efeitos, psicológicos ou materiais, dentro do mundo fenomênico".

A título de conclusão, James (1995, p. 308-309) refere-se aos aspectos gerais da experiência religiosa: trata-se de um "campo consciente mais seu objeto sentido ou pensado, mais uma atitude para com o objeto, mais o sentido do eu a que pertence a atitude". Seus fenômenos comuns podem ser assim esboçados: 
(...) admitem o eu dividido e a luta; envolvem a mudança do centro pessoal e o abandono do eu inferior; expressam a aparência de exterioridade do poder ajudador e ainda explicam o nosso sentido de união com ele; e justificam plenamente nossos sentimentos de segurança e alegria. (...) Basta-nos apenas acrescentar os pormenores específicos capazes de adaptá-los a várias teologias e temperamentos pessoais, e teremos então as diversas experiências reconstruídas em suas formas individuais. (JAMES, 1995, p. 314-315)

Desse modo, a função da experiência religiosa consiste em colocar o indivíduo em contado com uma esfera real, não necessariamente um esquema conceitual, mas uma sensação completa e absoluta, um conhecimento profundo e verdadeiro, "um pedaço concreto de experiência individual (...) em que surpreendemos o fato real em formação e percebemos diretamente como acontecem os eventos, e como o trabalho é realmente feito" (JAMES, 1995, p. 308-309). Enfim, a experiência religiosa permite nossa conexão "com as únicas realidades absolutas que conhecemos", que são nossas próprias experiências pessoais (idem, p. 311).

A conceituação e a teorização são os aspectos que se alteram no processo histórico de constituição e instituição das religiões, mas, de modo geral, o modo como operam os sentimentos e os processos intelectuais em relação ao ambiente são sempre os mesmos. Assim, "no fato de que a nossa pessoa consciente é contínua com um eu mais amplo através do qual sobrevém a experiência salvadora”, diz James (1995, p. 318 ), temos "um conteúdo positivo de experiência religiosa que, segundo me parece, é literal e objetivamente verdadeiro em toda a sua extensão". 


\section{III - A ARTE JAMESIANA DE ENSINAR}

Tendo analisado anteriormente neste trabalho as obras Talks to teachers on psychology (JAMES, 1889) e Variedades da experiência religiosa (JAMES, 1995), buscaremos cumprir neste capítulo a meta estabelecida em nossa seção introdutória, qual seja, discutir as relações que se podem estabelecer entre conceitos presentes nesses dois livros de William James, no intuito de indicar possíveis contribuições do pensamento jamesiano aos debates que atualmente se desenvolvem no campo da educação.

Para isso, faremos inicialmente uma seção contendo reflexões acerca desse campo, com o propósito de criar um terreno fértil onde lançar as ideias do filósofo. As seções subsequentes apresentarão as concepções jamesianas que julgamos passíveis de serem posicionadas no interior de tais reflexões. Nessas partes subsequentes, evitaremos fazer transcrições dos livros já examinados, dando preferência a utilizar o vocabulário que pudemos apreender nos capítulos anteriores para interpretar as relações que conseguimos estabelecer entre os conteúdos então apresentados.

\section{Uma reflexão sobre a educação contemporânea}

Discorrendo sobre as contribuições de John Dewey para a educação contemporânea, Cunha (2015a, p. 79) considera que

(...) nossas práticas educativas precisam ser guiadas menos por resultados, menos por práticas mercadológicas que privilegiam os resultados, como se a educação fosse um simples contrato entre vendedores e compradores, e mais pela satisfação inerente ao processo de educar.

Essa concepção tem como alicerce a crença deweyana de que "a educação pode ser diferente do que é hoje, porque as ações pedagógicas não acontecem no campo do necessário, mas no terreno da contingência", espaço em que ocorre o "debate honesto e aberto acerca de nossas aspirações e emoções mais profundas”, condição imprescindível para que se desenvolvam "deliberações morais".

Nessa reflexão, destaca-se o valor do diálogo e da comunicação, práticas que envolvem aspirações e paixões como elementos inerentes à vida, aos indivíduos como 
seres humanos que estabelecem relações mútuas. Destaca-se também a relevância do processo de decisão, quando estabelecemos, por meio de nossas emoções, o grau de importância das coisas. Todos esses elementos devem ser reconhecidos como relativos a atributos humanos próprios da vida, diferindo fundamentalmente da qualidade de dados passíveis de serem convertidos em variáveis matemáticas. Em acordo com Dewey, Cunha (2015a, p. 79) assinala que as atuais circunstâncias que enclausuram o campo da educação não levam em conta "a imaginação, os desejos e as emoções" e concebem o processo educativo como "algo estável, quantificável e frio".

É possível identificar no contexto educacional brasileiro atual "o fortalecimento da crença de que o poder da educação pode ser objetivamente medido". O senso comum diz que, "quanto mais quantificarmos o que acontece nas escolas, mais facilmente conseguiremos controlar o fenômeno educacional e, assim, mais facilmente conseguiremos colocar a educação a serviço do progresso do país”. As palavras "padronização", "avaliação" e "controle" lideram esse modo de operar no campo da educação (CUNHA, 2015b, p. 164)

Cunha (2015b, p. 166) sugere que é preciso ficarmos atentos para aquilo que não é sujeito a quantificação, ressaltando a necessidade de "problematizar o que acontece no interior do fenômeno educacional, não o que se apresenta em sua superfície”. Desse modo, o processo de avaliar os processos educacionais deve considerar a contingência, os sentimentos e a dimensão artística, componentes que remetem às artes práticas de criação cujos desenvolvimentos preenchem os espaços institucionais de ensino. Deve-se estar aberto para assumir um modo estético de proceder no âmbito da produção de conhecimento.

Hansen (2005) também entende a dimensão estética como fundamental para a prática educativa, juntamente com as dimensões moral e intelectual. Esses três elementos constituem a base para a edificação de uma educação poética, caracterizada em consonância com o termo grego poiesis, uma técnica que resulta na criação de algo original. Hansen acredita que o processo educativo é constituído pela trama de gestos e comportamentos dos alunos e pelo olhar atento de professores, integrados a uma ação criativa e transformadora. Cunha (2015a, p. 79) explica que as reflexões de Dewey “podem suscitar em nós o desejo por formas de educação mais inventivas, mais humanizadoras, distanciadas do modo como vêm sendo tratadas as problemáticas educacionais na atualidade". 
O atual cenário pedagógico caracteriza-se por uma marcante preocupação com as temáticas da gestão, principalmente a gestão em rede orientada por modelos empresariais, ocupada em levantar dados sobre diferentes escolas, visando estabelecer políticas com base em indicadores advindos de avaliações em larga escala, o que assume uma dimensão política importante para a organização de grandes sistemas públicos de ensino. Essa perspectiva puramente política, focalizada em ações de grande amplitude, acaba por diluir componentes que estão no cerne das problemáticas educacionais, conforme assinalam os pesquisadores que ressaltam a complexidade do processo educativo e questionam as avaliações padronizadas e os currículos centrados unicamente em conteúdos - medidas fomentadas por políticas públicas que visam facilitar o acompanhamento estatístico do desempenho dos alunos (CUNHA, 2015a; CUNHA, 2015b; HANSEN, 2005; HANSEN, 2007; PODESCHI, 2002).

O sistema de ensino pensado exclusivamente na vertente política da gestão de redes educacionais minimiza o valor de processos que constituem o núcleo não apenas do processo educativo, em si mesmo, mas da escola como um todo. A escola é sujeita a regimentos, leis e garantias que afetam os sujeitos que dela participam, mas ainda assim possui um modo particular, não universal, de funcionamento prático. Embora tenha uma constituição própria, difícil de ultrapassar ou modificar, a escola reflete uma tensão entre os propósitos estabelecidos pela legislação e as práticas efetivadas em seu interior, o que muitas vezes desenha um espaço conflituoso.

Os caminhos por onde a escola forja suas atividades são definidos nas interações que ocorrem entre alunos, entre professores e também entre alunos e professores, sem desprezar o ambiente mais amplo que compõe a instituição de ensino - os funcionários de vários níveis, o mobiliário das salas de aula, o desenho arquitetônico do prédio, o entorno constituído pelas famílias e por outros agentes sociais. A contingência é a característica predominante de espaços que não operam com o necessário, mas com possibilidades, com a criação de situações voltadas à concretização de propósitos, o que confere relevância máxima aos hábitos dos sujeitos que ocupam tais espaços.

Esses hábitos precisam ser sintonizados com os propósitos firmados coletivamente, para que se torne possível articular ações significativas. A formação de comportamentos é decisiva nesse processo, não se tratando de condutas padronizadas, mas de formas de reagir criativamente, exprimir reações capazes de reconhecer o contexto e suas práticas e intervir sobre o que se apresenta, de modo a abrir novos horizontes para todos os envolvidos. Na reflexão apresentada por Quintiliano (2012, p. 
379), a questão central diz respeito a "conciliar transmissão de saberes, aprendizagem de regras sociais e costumes, com a possibilidade de uma ação livre e independente dessas mesmas regras", pois existe um tensionamento entre a afirmação da subjetividade e as normas vigentes, tanto no espaço escolar quanto em qualquer agrupamento social.

No que tange à atuação de professores, cujos propósitos repousam na "universalidade de um saber já confirmado", Quintiliano (2012, p. 398) afirma ser “contraditório pensar uma libertação ou uma emancipação por modelos de reprodução do idêntico, de repetição acrítica de noções, ideias ou preceitos". Os conceitos e os conteúdos lógicos são "formas puras", ao passo que a preparação do indivíduo para a vida habita o terreno das "meras possibilidades de percurso para um devir livre, para um devir responsável, para um devir cidadão" (idem, p. 400). Qualquer intervenção decorre de escolhas, o que remete a juízos de valor, ponderações sobre o que é bom ou ruim, apropriado e inapropriado, sinalizando ideais, novos caminhos.

Nossos juízos são dependentes de nossas paixões, de nossa afeição por determinados objetos e aversão por outros. Não se trata de defender, aqui, a constituição do cenário escolar como resultado exclusivo da variação de temperamentos e sentimentos, mas é preciso enfatizar que estejamos atentos para reconhecer o quanto as pessoas são diferentes, cada qual munida de sentimentos que afetam a construção de seu caráter e, portanto, de sua conduta pública. É na ponderação entre sentimentos e impulsos, de um lado, e o contexto coletivo, de outro, que se instaura o estímulo para a deliberação, e só se pode deliberar de maneira justa se os fatores envolvidos forem corretamente identificados.

As paixões ocupam lugar decisivo no curso das práticas escolares, as quais englobam o comportamento dos alunos tanto nas salas de aula quanto nos intervalos, sua relação com os outros alunos e com os demais membros da instituição de ensino. Não há ruptura entre seus comportamentos e seus sentimentos, e se o que se pretende é formar condutas criativas que não apenas respondam mecanicamente ao meio, mas que criem e signifiquem esse meio, é preciso admitir o papel das paixões nesse processo. Definir os rumos da escola é uma operação que requer a compreensão do papel da escola na instituição de comportamentos e sentimentos.

Empreender políticas públicas, por mais corretas que sejam as suas intenções, pode ser uma forma cega de atuação, especialmente quando se desconsidera que a escola habita um universo relacional cujo impacto é, invariavelmente, social, articulado 
na interface entre comportamentos e sentimentos. Cada escola deve reconhecer as paixões que mobilizam seus integrantes, pois são elas que transportam o potencial de construir novas formas de interação capazes de fomentar comportamentos de reação, habilitando os alunos a deliberar em meio à incerteza, de modo completo e justo.

Essa concepção coincide com a qualificação de Crick (2015, p. 174) sobre a missão dos professores, ou, em suas palavras, a "fé da pedagogia radical". O processo de comunicação instaurado no interior da relação de ensino envolve a canalização de impulsos, uma canalização positiva, compreendida no modo como John Dewey conceitua sublimação, uma purificação da ação com vistas a aperfeiçoar impulsos ou sentimentos que, de outro modo, poderiam extravasar como "irritações explosivas e sonhos de grandeza". Na esfera da comunicação, a sublimação constitui uma composição retórica, denotando arranjos inteligentes articulados na esfera de um "ambiente mais estruturado e criativo".

A noção de retórica apresentada por Crick identifica-se como arte criativa, referente ao que é produzido, fabricado pelo esforço do indivíduo, podendo ser efetivada no processo educativo, contanto que haja condições suficientes para isso. Crick (2015, p. 174) busca fundamento para o processo de composição e organização das energias individuais na formulação deweyana de que é preciso "desenvolver uma forma de educação cuja meta consiste em aproveitar as energias atuais dos estudantes e canalizá-las por meio de experiências pedagógicas", tendo por meta "cultivar hábitos de crescimento".

Este é o cerne do que se define como "pedagogia retórica" (Crick, 2015, p. 179). Diferentemente da "pedagogia tradicionalista", que vê a energia dos alunos, seus impulsos e sentimentos como uma "fonte de distração" que os afasta das matérias escolares, a pedagogia retórica utiliza essas mesmas energias, impulsos e sentimentos para levar o educando a criar, por meio da instituição de "hábitos de inteligência criativa e juízo ético capazes de crescimento contínuo" (idem, p. 174-175). Nessa abordagem, a escola é fundamental para a obtenção de uma vida mais ampla que comporta as dimensões intelectuais, emocionais e artísticas, e capacita os estudantes a se tornarem cidadãos críticos e participativos. Ver a escola em sua complexidade é requisito para entender que o significado da educação advém das ações concretas dos alunos e dos professores, não cabendo no estreito limite das definições acadêmicas, políticas e legislativas - estas, na verdade, é que deveriam elaborar suas proposições em sintonia com a configuração real do universo escolar. 


\section{Religiosidade e educação: fenômenos complexos e plurais}

Conforme analisamos anteriormente neste trabalho, a noção de ensino como arte elaborada por James (1899) em Talks to teachers on psychology traduz a possibilidade de ampliação dos horizontes humanos de compreensão e sensibilidade. O filósofo cunha a referida expressão com o propósito de distinguir o trabalho docente das práticas científicas, procurando mostrar que o ofício de ensinar envolve sensibilidade, tato, prontidão, características associadas a uma dimensão mais profunda do indivíduo, sendo exteriorizadas em uma relação ética que remete à criação de valores e significados.

Ao tecer considerações sobre valores morais nessa mesma obra, James (1899, p. 277) refere-se a um "sentido de visão ampliada" que se pode definir como um "aumento da percepção religiosa no interior da vida". O desenvolvimento da capacidade de perceber os valores dos outros corresponde ao que o autor denomina "religião da democracia", cujo "crescimento permanente" tende a ocorrer nos contextos em que aquela capacidade é cultivada (idem, p. 278).

Com essas reflexões, a educação é elevada ao patamar de fenômeno complexo, o que fica evidente quando James (1899, p. 295-296) traça os seus contornos por meio de diferentes matizes de percepções, sentimentos e determinações que requerem "algum tipo de fusão, alguma combinação química desses princípios para resultar numa vida objetiva e completamente significante". Ao lidarmos com valores e significados para a vida, as "conclusões nunca podem ser precisas" e as "respostas da apreciação, do sentimento, sempre se dão como mais ou menos", constituindo "uma ponderação tangenciada pela simpatia, pela percepção e pela boa vontade". Nesse processo, torna-se possível ampliar nossa imaginação, o que nos permite ampliar também nossa riqueza interior, nossa sensibilidade para os componentes da vida, o que James caracteriza como “inspiração religiosa”.

A concepção de experiência apresentada em Variedades possui essa mesma complexidade, pois diz respeito a ampliar significativamente as nossas concepções e sentimentos relativos à vida. Ao discorrer sobre o método adotado para o estudo da referida experiência, James (1995, p. 29) alerta que "muito provavelmente não encontraremos uma essência única, senão muitos caracteres que podem ser, de forma alternada, igualmente importantes na religião". E diz também que "estamos lidando com um campo da experiência em que não há uma única concepção que possa ser tratada 
com nitidez", pois o excesso de rigor ou exatidão apenas revela a nossa falibilidade (idem, p. 36).

Observa-se nessas reflexões a dimensão de pluralidade inerente à experiência religiosa, pois se trata de desenvolver sensibilidade para valores e significados que são alheios a nós, assumidos por outros. É a mesma pluralidade que se pode notar em Talks, quando o filósofo afirma que a riqueza interior, tanto a nossa quanto a de outrem, tem mais valor do que muitos conceitos, termos técnicos e conteúdos escolares. De modo geral, em ambas as obras se observa a temática da composição holística analisada por Putnam (1995, p. 7) como traço fundamental do pensamento jamesiano. Tanto ao abordar a experiência religiosa quanto ao discorrer sobre educação, James nos situa diante de realidades complexas e plurais que comportam inúmeras variáveis e produzem arranjos específicos de acordo com situações particulares.

Diante dessas considerações à luz da experiência religiosa, a noção jamesiana de ensino como arte pode ser entendida como relativa a uma experiência educacional ímpar, complexa e plural cuja eficácia não se pode conhecer com antecipação, nem ser desvendada por intermédio de ferramentas de mensuração. Quando a prática de ensinar é exercida como arte, todos os componentes de uma proposta educacional - os conteúdos das disciplinas, a avaliação da aprendizagem, a gestão escolar e os ditames da legislação, entre outros - são passíveis de combinações variáveis e imprevisíveis.

\section{A formação de novos hábitos: educar para a diversidade}

A complexidade e a pluralidade da educação ficam evidenciadas nas reflexões acerca da formação de novos hábitos feitas em Talks. Tais reflexões remetem à noção de comportamento como algo que diz respeito, ao mesmo tempo, a um cultivo, uma sensação e uma preparação. Como cultivo, o comportamento é semelhante a um treinamento esportivo no qual o futuro atleta aprende os movimentos próprios da modalidade, o posicionamento corporal, a organização tática, e assim vai desenvolvendo as habilidades que dele se espera. Como sensação, o comportamento envolve reconhecer e compreender nossas paixões, notando que algumas não são apropriadas por colocarem em risco ou desrespeitarem outras pessoas, o que resulta em ações contrárias às demandas passionais. Como preparação, o comportamento é uma reação adaptada, ou ajustada, implicando certa antecipação das adversidades, de modo a ajustar o indivíduo ao ambiente. 
Educar, para James, é formar hábitos, instituir comportamentos novos, seja na escola ou em outro espaço qualquer, e isso implica mudança. As mudanças são elementos característicos da vida, pois correspondem a novos hábitos, como vimos em Talks. Diante da noção de comportamento acima mencionada, um hábito é uma complicação, ou substituição. Trata-se de uma complicação por situar um novo objeto, seja uma imitação, um novo significado ou uma nova conduta, em meio ao estoque de experiências, memórias e ideias que já possuímos, o que constitui uma acomodação, um enquadramento do novo sem acarretar prejuízos para o conjunto de nossas experiências. Como substituição, um hábito é a troca do existente pelo novo, processo que desencadeia mudanças significativas no indivíduo.

Por mais apropriado que seja, um hábito novo enfrenta dificuldades para se formar quando se defronta com ideias e experiências que o contrariam, fazendo-se necessário um esforço para não comprometer as verdades já estabelecidas pelo indivíduo, ou para que tais verdades sejam reconhecidas como ineficientes e substituídas. Putnam (1995, p. 14-15) mostra que certas teorias científicas costumam ser tão diferentes e inovadoras que passam por desacreditas, como fantasias da mente humana, excentricidades, sendo preciso discutir "o que é explicativo e o que não é, o que é coerente e o que não é”. Quando o conflito entre novas experiências, novos fatos, novas teorias, torna-se muito acirrado, a tensão costuma "cruzar fronteiras" e misturar questões científicas, culturais e metafísicas compondo um emaranhado do qual é difícil sair.

As pessoas aprendem muitas coisas durante sua vida, não apenas em instituições de ensino, mas também nas relações em geral, nas conversas informais, no empenho para copiar outros indivíduos ou modos de pensar, nas ocasiões em que assimila doutrinas religiosas, na esfera da vida em família etc. Tais aprendizados acarretam mudanças na forma como agimos e no modo como nos expressamos, influenciando na definição de nossa identidade. O estudo de James sobre a religiosidade contribui para compreendermos a tensão que se estabelece entre essas várias instâncias de aprendizagem, pois a experiência religiosa diz respeito a uma transformação que põe o sujeito em um novo centro emocional, o levando a assumir um novo conjunto de condutas.

As proposições educacionais de James questionam o modo como o indivíduo é preparado para enfrentar novidades e decidir sobre as situações da vida que o limitam a comportamentos específicos, restritos, que anulam outras novidades e o deixam cego 
para novas formas de conduta. A disposição pluralista e favorável à interdisciplinaridade assumida por James em Talks é uma crítica à nossa dificuldade para formar juízos de valor sobre formas de vida diferentes da nossa. O sentido radical da educação jamesiana reside no reconhecimento de nós mesmos a partir do reconhecimento do outro. Não se trata de nos subjugarmos a ideais alheios, mas de conseguir enxergá-los como são, primeiro passo para tornar mais significativos os nossos próprios ideais.

Educar o comportamento, então, é preparar o indivíduo para a diversidade, sem comprometer sua individualidade, seu caráter, sua personalidade. Isso só acontece, segundo James, por intermédio de um processo educativo permeado por criatividade, por estratégias pedagógicas que estimulem a ação criativa dos alunos. No vocabulário jamesiano, ser criativo e possuir individualidade, originalidade, é ser capaz de criar novos significados, conceituação que encontra respaldo nas reflexões do filósofo acerca da religiosidade. A experiência que James qualifica como religiosa ilumina a ideia de formar comportamentos que habilitem para o mundo, para uma vida plena de contatos mais profundos com nossos semelhantes.

Os elementos que podem auxiliar na formação de comportamentos abertos à pluralidade da vida estão presentes na própria vida, nas relações ordinárias entre os indivíduos. Em Talks, James (1899, p. 136) diz que os professores devem ter "olhos em suas cabeças e bom senso, e algum sentimento para os fatos concretos da natureza humana em seus corações". Na vida também é preciso ter atenção, abertura de espírito e sensibilidade para relações mais profundas e significativas com o mundo e com os outros. Ao assumir esse posicionamento no campo educacional, nos situamos no âmago da experiência religiosa definida por James, uma experiência que viabiliza o engendramento de conexões criativas.

Essas concepções possuem um caráter político, pois, ao valorizar a originalidade de cada indivíduo e a pluralidade da vida, James (1899, p. 278) clama por uma "religião da democracia", como vimos em Talks. Para o filósofo, a dimensão religiosa caminha lado a lado com a dimensão intelectual, cada qual cumprindo seu papel e auxiliando na reconstrução da outra. No lugar de uma ordem social que premia posições hierárquicas e promove a separação entre os indivíduos, James prega a humanização das relações entre as pessoas, único meio para efetivar nosso potencial de criatividade. Ao abrir canais de comunicação para o intercâmbio de ideias e significados novos, podemos instituir um processo educativo que habilite o estudante a trabalhar com a diversidade inerente a 
situações problemáticas cuja solução requer o envolvimento de todos; uma educação que incentive ações marcadas pelo reconhecimento das diferenças.

\section{Adaptação e transformação: abertura para o novo}

A teorização acerca da formação de hábitos feita por James em Talks diz respeito a posicionar uma nova ideia ou experiência no conjunto de ideias e experiências que já possuímos e que respondem por nossas decisões. Modificar o estoque de comportamentos existente implica mudar o modo como o indivíduo delibera, o deslocando de uma zona de conforto para o âmbito de uma aventura incerta. Faz-se necessário, nessas ocasiões, desenvolver um processo adaptativo que requer o esforço do próprio indivíduo, tal qual o descrito pelo filósofo no tocante à experiência religiosa.

Segundo vimos em Variedades, esse processo envolve uma busca por equilíbrio que mobiliza tanto as esferas profundas quanto as esferas superficiais do pensamento. $\mathrm{O}$ processo denominado conversão exprime a passagem de um estado de perturbação e incoerência para um estado de equilíbrio e prontidão, o que, de acordo com James (1995, p. 259), ocorre quando passamos "de um menos para um mais, de uma pequenez para uma vastidão", e a direção de nossa vida segue uma perspectiva de progresso.

A dimensão adaptativa que James encontra na experiência religiosa é descrita de modo semelhante por vários autores. John Dewey (1959, p. 51), por exemplo, ilustra suas ideias sobre esse tema evocando o cenário em que um grupo de pessoas chega a uma planície deserta e, em vez de se ajustar às condições dadas, assume condutas ativas, irrigando o solo e pesquisando as plantas e os animais que ali habitam, até que o deserto floresça. Franz Boas (1888 apud COLE, 1983, p. 34), por sua vez, ao estudar uma comunidade de esquimós, notou que o grupo não se submetia aos ditames do ambiente hostil, mas colocava tanto as suas crenças quanto as suas técnicas de caça e construção de habitações a serviço da sobrevivência ${ }^{17}$. Segundo Cole (1983, p. 33), as observações de Boas o levaram a afirmar que o valor de uma pessoa deve ser compreendido com base em seu Herzensbildung, palavra alemã que designa uma educação de coração, um autoconhecimento que coloca em sintonia o amadurecimento pessoal e as condições culturais, remetendo a imaginação, criação e novas formas de pensar.

17 BOAS, Franz. The central eskimo. Washington: Government Printing Office, 1888. http://www.gutenberg.org/files/42084/42084-h/42084-h.htm Acessado em 16/05/2017. 
Tanto nesses dois autores quanto em James, podemos compreender o mecanismo de adaptação como conjuntos de ações articuladas para fazer frente às condições concretas do ambiente mediante esforço dos indivíduos; nos apropriamos do que é imediatamente oferecido e, ao mesmo tempo, agimos para transformar os elementos dados, visando extrair deles um benefício. A simples reprodução de comportamentos já instalados não é suficiente para ocasionar a adaptação e, consequentemente a transformação, fazendo-se necessário desencadear um processo que viabilize o florescimento do deserto, como diz Dewey, o que requer, em consonância com as concepções de Boas, uma formação que incentive a imaginação e a criação.

Ao caracterizar a religiosidade, James refere-se a uma experiência que torna as pessoas sensíveis à mudança, livres de restrições impostas por seus comportamentos habituais. A experiência religiosa envolve o entendimento das condições de fato e a disposição para atribuir significados diferentes ao que já existe. Como afirma James (1995, p. 41), tal experiência vai além da "moral propriamente dita", sob a qual o indivíduo poderia apenas aquiescer. Em suma, trata-se de criar algo novo por intermédio de um arranjo mental competente para apreender o ambiente e ultrapassar as restrições por ele determinadas.

Transportando essas reflexões para o campo educacional, encontramos em Masschelein e Simons (2014, p. 289) a ideia de que a escola deve ser um espaço "profano" que não se identifica com "um lugar de vazio", mas com "uma condição em que as coisas (práticas, palavras) estão desconectadas de seu uso regular", sugerindo que “alguma coisa do mundo está aberta para o uso comum”, uma liberdade ativa, um "libertar para", não um "libertar de" (idem, p. 288).

Essas concepções ecoam as teses de John Dewey, para quem, segundo Cunha (2015a, p. 10-11), educar é socializar, integrar um indivíduo aos valores e significados compartilhados por sua coletividade; educar é estabelecer meios efetivos para vincular “alguém já socializado, que detém os saberes e padrões socialmente aceitáveis e quer torná-los comuns" e "um ser não plenamente socializado, que ainda não conhece os parâmetros da comunidade na qual está destinado a viver e que precisa conhecê-los". Cabe à educação cumprir dois objetivos intimamente associados: "reter das gerações passadas o que há de melhor e, ao mesmo tempo, superar modos ultrapassados de ver o mundo; adequar o novo ao velho e, ato contínuo, ajudar os educandos a transgredirem padrões já estabelecidos". 
A liberdade para de que nos falam Masschelein e Simons e a conceituação deweyana dos objetivos da educação é o que encontramos nas reflexões em que James caracteriza a educação como um meio de formar para a vida, uma experiência única em que o indivíduo assimila o que existe e mostra disposição para transformar o mundo, começando por transformar o seu próprio comportamento, à semelhança do que se passa na experiência religiosa. A noção jamesiana de ensino como arte e a concepção de James acerca da religiosidade envolvem admitir a mudança permanente das coisas como requisito para a constituição de um novo homem.

O homem a ser formado pela educação concebida como arte tem por modelo o "homem sábio" a que se refere James (1995, p. 201) em Variedades: é aquele que se mantém aberto à transformação, consciente de que as verdades são provisórias e que uma ideia só pode assumir o caráter de verdade para um indivíduo quando atualizada em conjunto com os demais indivíduos. No âmbito da religiosidade, então, é que esse homem alcança a visão dos "horizontes mais amplos da verdade". Quando discorre sobre educação em Talks, James (1899, p. 241) apresenta caracterização semelhante para tratar da ampliação de horizontes e da capacidade de se abrir aos sentimentos alheios, qualidades do homem a ser formado que só se observam em alguns filósofos, poetas e romancistas, ou quando "o homem prático se apaixona".

As paixões desempenham papel altamente relevante na abertura para o novo, constituindo o que chamamos anteriormente de fio condutor do discurso elaborado pelo filósofo em Talks to students. São as paixões que nos levam a deliberar por este ou aquele caminho, liberando ou obstruindo a nossa capacidade de conferir significado às coisas e a nossa disposição para interagir com os outros. Faz-se necessário, portanto, não liberar indistintamente as emoções, nem tentar exercer controle absoluto sobre elas, o que James considera impossível de ser feito. O espaço em que a atividade educativa consegue atuar é o da formação dos hábitos, a modulação das condutas.

Em Variedades, encontramos indicações sobre como efetuar esse propósito, quando o filósofo diz que as várias discordâncias experimentadas pelo indivíduo o conduzem a um ápice que resulta na composição de seu caráter. $\mathrm{Na}$ esfera da religiosidade, James (1995, p. 174) dá o nome de santidade ao estado em que conseguimos alcançar os frutos amadurecidos da experiência, que é quando as paixões, uma vez adequadamente tratadas, engendram condutas guiadas por um sentido de moralidade. As emoções, então, constituem o "caráter santo", ocupando o "centro habitual da energia pessoal". Nestas reflexões, fica evidente que cabe à educação 
promover meios para que os estudantes alcancem o referido estado, o que exige dos professores estratégias de trabalho diferenciadas, que envolvam formas de comunicação inovadoras com os educandos.

\section{Comunicação: território do inefável e da expressão artística}

A temática da comunicação associada ao campo das paixões pode ser discutida no âmbito das proposições educacionais jamesianas, quando em Talks o filósofo faz referência a certo "segredo interno". Segundo James (1899, p. 263-264), tal segredo possui a qualidade de inefável, indizível, pois escapa aos recursos discursivos. E é fundamental "sentir o próprio segredo interno", dar vazão ao processo mágico da vida sensorial para alcançarmos a máxima felicidade.

É na vivência plena desse segredo que nos tornamos abertos ao outro, desenvolvendo sentimentos de respeito e compreensão e a capacidade de perdoar até mesmo atitudes que são ininteligíveis para nós. Quem consegue estabelecer relações humanas mais profundas fica mais próximo da verdade por ter o coração repleto de generosidade, mas o que se passa no interior de cada um de nós não pode ser comunicado, como admite James (idem, p. 268) ao dizer que, por sermos seres práticos, nossos segredos permanecem "impenetráveis aos outros".

Ao analisar a discussão sobre a inefabilidade feita pelo filósofo em Variedades, obtemos uma visão mais ampla de sua concepção educacional no que tange às possibilidades da comunicação. James (1995, p. 237-238) explica que a inefabilidade, um dos estados místicos que viabilizam a experiência religiosa, diz respeito a paixões, sentimentos que não se podem expressar em palavras, uma vez que não contêm o necessário encadeamento lógico. Essa caracterização faz sentido porque as experiências místicas possuem significações que não podem ser apreendidas exclusivamente por sistemas racionalmente articulados, o que evidencia um problema para a educação, se entendermos a prática pedagógica como destinada a formar comportamentos por meio da transmissão de conhecimentos e valores, como o próprio James sugere.

Mas o filósofo oferece uma solução para esse problema ao dizer que os conteúdos inefáveis podem, sim, ser comunicados, desde que veiculados por intermédio de experiências realizadas em comum, como são as expressões artísticas - a música, a poesia, a literatura etc. Vale transcrever novamente o trecho em que James (1995, p. 239) apresenta a referida solução, pois nele se encontra uma importante contribuição para pensarmos a educação: "Palavras singelas, conjunções de palavras, efeitos de luz 
na terra e no mar, odores e sons musicais" podem provocar experiências místicas "quando a mente está corretamente afinada". Por esses meios, portanto, é possível acessar o inefável inerente a determinados estados místicos. A "unidade do homem com Deus" é expressa em discursos não pertencentes ao universo da linguagem, é verdade, o que não quer dizer que uma experiência desse tipo esteja além da compreensão humana, pois a música e a poesia cumprem esse propósito.

Podemos inferir, portanto, que a comunicação, e a comunicação no âmbito educacional, em particular, é vista por James como possível, ainda que esse campo seja composto, em grande parte, por experiências inefáveis. Como assinala Cunha (2005, p. 9-10), ideia semelhante é afirmada por Dewey, para quem a comunicação - elemento fundamental na conceituação deweyana de sociedade - não se restringe à linguagem falada e escrita, englobando um variado "conjunto de sinais que expressam valores e conhecimentos", pelos quais a experiência torna-se "patrimônio comum, partilhado e desfrutado por todos".

É por admitir essa possibilidade que James se dispõe a comunicar as suas concepções psicológicas a professores e estudantes, pois, caso contrário, seria absolutamente inútil fazê-lo. O que move o filósofo é a esperança de que tais concepções possam contribuir, de algum modo, para modificar o comportamento daquela audiência, a levando a assumir condutas humanizadoras. James sabe que a educação não se resume à aplicação mecânica de conteúdos programáticos e à reprodução de enunciados científicos; faz-se necessário atribuir significado ao que se ensina, e os significados devem resultar de deliberações coletivas. Para cumprir essa tarefa, o professor deve ter sua atenção especialmente voltada para a construção de estratégias comunicativas.

Seguindo a abordagem pragmatista que lhe é própria, James utiliza a estratégia comunicativa de destacar os aspectos práticos de sua teorização ao expor suas teses àquela audiência. Para ele, a arte de ensinar requer uma teoria voltada à ação, considerando as consequências dos conceitos teóricos na atuação profissional dos professores e na conduta a ser assumida pelos estudantes. A mesma estratégia é adotada pelo filósofo no estudo da religiosidade, cujo objetivo é investigar as possibilidades e consequências práticas do envolvimento da pessoa em uma experiência religiosa.

No que tange à prática, a experiência religiosa é caracterizada pelo filósofo como algo que, originado no âmago da individualidade, possui significativa dimensão exterior, pois ao vivenciá-la o indivíduo não permanece aprisionado em si mesmo. 
James (1995, p. 269) considera necessário "redimir a religião do exclusivismo insalubre, e dar status público e direito universal de passagem às suas mensagens", e essa vem sendo "a tarefa da razão", não uma razão com intuito doutrinário, mas dedicada à argumentação, à comunicação, capaz de retirar a religiosidade da redoma privada em que ela se origina. O "ideal mais caro" do intelecto é encontrar meios para fugir da "obscura persuasão pessoal", colocando o discurso a serviço da "verdade objetivamente válida para todos os homens pensantes". ${ }^{18}$

$\mathrm{Na}$ proposta jamesiana de educação como arte, essa meta se consolida por intermédio da ciência, como o próprio filósofo sugere, mas também por meio de expressões artísticas capazes de apreender o inefável, o que requer um tipo especial de comunicação, uma forma de persuasão que opere com as paixões. A comunicação que lida com sentimentos necessita estratégias criativas que ponham a individualidade na esfera da coletividade. Do sucesso desse empreendimento depende a transformação dos hábitos e a concretização da democracia.

\section{Educação como arte}

Em James, a separação entre arte e ciência constitui uma distinção, não uma separação absoluta, servindo para delinear os qualificativos da docência. Os professores, em sua época de formação, aprendem que teorias e técnicas científicas têm caráter definitivo, mas o filósofo mostra que há algo mais a ser considerado na elaboração de programas de ensino e na adoção de métodos didáticos. Os ensinamentos da ciência devem efetuar um diálogo entre as várias teorias, buscando aperfeiçoá-las ou ajustá-las a situações reais, processo em que a prática cotidiana assume posição privilegiada.

Essa distinção, em cuja base reside a definição de educação como arte, remete aos conceitos gregos de episteme e techné, sendo o primeiro relativo a um conhecimento exclusivamente teórico, geralmente destinado a fins contemplativos, e o segundo, a um empreendimento prático que visa dar forma a algo novo de acordo com as circunstâncias que se apresentam, constituindo uma arte prática (GARRISON, 2008). A possibilidade de criar está na essência do ensino, esfera em que não cabe reproduzir com exatidão os conhecimentos científicos, mas construir canais para que as teorias sejam direcionadas em consonância com as diversas situações.

\footnotetext{
${ }^{18}$ Traduzimos essas palavras diretamente do original por não encontrar o seu sentido preciso na versão para a língua portuguesa: "to find a scape from obscure personal persuasion to truth objectively valid for all thinking men has ever been the intellect's most cherished ideal" (JAMES, 1917, p. 423-424).
} 
Se as teorias fossem aplicadas tal qual são elaboradas, teríamos uma doutrinação. Como existem muitas teorias, que tanto se reforçam como se opõem mutuamente, o ensino reprodutivista é evidentemente fragmentado. Seguindo as concepções de James, devemos reconhecer o valor das teorias científicas para a docência, extrair delas o máximo possível para minimizar erros e, assim, ampliar a margem de acerto dos professores.

De modo semelhante ao que se deu na virada do século XIX para o XX, a tensão entre teoria e prática faz-se presente na atualidade em todo o campo das ciências do homem, particularmente na educação (MAZZOTTI, 2006, p. 542). Como vimos no primeiro capítulo deste trabalho, o apelo de Ferreira (2010) para retomar os estudos da filosofia de James surge em decorrência da insatisfação dos estudantes que, não encontrando meios para efetivar as teorias na prática, voltam-se contra a própria teoria e a organização de programas de estudos teóricos. Cunha (2010, p. 233) alerta que "esse efeito já se anuncia nos cursos de formação de professores, uma vez que os aspirantes à carreira docente são tão afetivamente tocados por ideias inovadoras quanto descrentes de sua efetivação". Nos meios acadêmicos, difunde-se a ideia de que a "teoria é boa, mas na prática não funciona".

James (1899, p. 8) confronta as noções advindas de corpora teóricos sistematizados em gabinetes universitários com as práticas que correspondem a essas mesmas noções. Seu intuito é mostrar que quem se dedica ao estudo da ética não é necessariamente uma pessoa cujo comportamento incorpora os valores arrolados pelos tratados de ética. Do mesmo modo, quem se dedica ao campo da lógica também não necessariamente adota, em seu cotidiano, os raciocínios indicados pela ciência que estuda. James (idem, p. 7) sustenta que a ciência não permite "deduzir programas, esquemas e métodos de ensino para uso imediato na sala de aula". A ciência não gera necessariamente a arte, a techné competente para abordar situações reais de ensino. $\mathrm{O}$ que é fundamental para alcançar esse fim é a intervenção de uma mente dotada de originalidade, empenhada em romper a falta de originalidade ocasionada pela padronização que suprime as individualidades ao adotar cópias reprodutoras de teorias científicas.

Uma leitura radical das proposições jamesianas sugere que não há método, teoria ou programa de ensino que seja passível de aplicação universal. O que há são formas criativas de interpretar situações e investigar em que medida algumas teorias se mostram aplicáveis, e outras, inviáveis no cotidiano escolar. A possibilidade é um 
componente característico da zona de reflexão em que se enquadram as concepções jamesianas: o presente, o atual, é onde se distingue o possível do inaplicável. É no cenário da possibilidade, no avesso do campo da necessidade, que se impõe a urgência da originalidade. É no intervalo entre o que existe de fato e o que pode vir a existir, é nesse intervalo incomensurável que se situa a atividade docente criativa decorrente das proposições de James.

Para situar James no cenário pedagógico e educacional da atualidade, devemos recontextualizar as suas ideias com ênfase na liberação do potencial criativo dos indivíduos mediante o reconhecimento de que o mundo e as relações entre os homens estão em constante transformação. As atividades e os valores humanos que lhes oferecem sustentação devem ser sempre ajustados a circunstâncias adversas, o que exige ações inovadoras que restaurarem o equilíbrio perturbado pela tensão inerente à mudança. Esse é o propósito que se espera da educação, e a experiência religiosa conceituada por James pode nos auxiliar a delinear os caminhos a serem seguidos pelos agentes educativos.

Tanto em seu estudo sobre a religiosidade quanto em seu livro dedicado a professores e estudantes, James destaca o valor da experiência dotada de originalidade, autenticidade. Uma experiência com esses atributos é a que realiza o contato do indivíduo com o que se considere divino ou sagrado, não necessariamente intermediado por alguma religião ou doutrina espiritual. Na esfera educacional, esse tipo de experiência é a que se desenvolve através de um canal efetivo de comunicação entre professores e alunos, de modo a veicular noções científicas e, principalmente, dar vazão ao indizível, promovendo o transbordamento controlado das paixões.

As ações educativas produzem alterações nas pessoas, e devem fazê-lo por meio de ações que James denomina unidades práticas, construtos que integram os conteúdos escolares, como também as memórias, as experiências anteriores, as ideias velhas e as ideias novas dos estudantes. As ações verdadeiramente educativas não são instintivas, frutos da eclosão das paixões, mas resultantes de um programa voltado à promoção da individualidade do aprendiz, retomando ao que James conceitua como fluxo de consciência. Cada indivíduo é um arranjo singular; as diferenças não são obstáculos a serem superados, mas qualidades a serem cultivadas, pois nelas reside o potencial criativo do aluno. Cabe ao educador produzir arranjos para que o diálogo entre as diferenças aconteça, alicerçado em uma plataforma de interação que viabilize a pluralidade no espaço escolar. 
Os acontecimentos que se verificam na escola necessitam ser interpretados, como diz Hansen (2005, p. 111), para que possamos conceber o universo escolar como "expressivo", como algo que integra as diversas "expressões do mundo". Cabe ao professor realizar essa interpretação, em busca da "revelação concreta da natureza humana nos gestos, palavras e ações dos alunos”. É nesse esforço interpretativo que o docente se torna capaz de criar uma via de comunicação autêntica com os alunos, uma relação de proximidade que envolva a sensibilidade de ambas as partes. Quando a esse esforço integram-se os conhecimentos científicos, realiza-se a meta de toda educação, que é vincular os objetos da instrução ao universo íntimo do aluno.

Esse modo de enxergar a si mesmo e a seus alunos leva o professor à “apreciação crítica”, o que, nos termos de Hansen (2005, p. 108-109), significa ir além dos fatores mensuráveis. Trata-se daquele canal de comunicação que permite saber "algo sobre o aluno como um ser humano, com qualidades distintivas, interesses, preocupações, fragilidades e pontos fortes”. Para James, o que realmente importa na avaliação dos estudantes não são resultados quantificáveis, mas a vontade, a determinação, a paixão e o interesse em dar continuidade à experiência do aprendizado. A proposta jamesiana de conceber a educação como arte nos leva a pensar a instituição de ensino como um espaço rico de interação e troca, em que se firmam laços de solidariedade e afeto voltados ao progresso intelectual - em suma, um espaço democrático. 


\section{CONSIDERAÇÕES FINAIS}

A investigação feita neste trabalho acerca das obras Talks to teachers on psychology e As variedades da experiência religiosa revela o pioneirismo de William James, não só no campo da psicologia, como também no da educação e, acima de tudo, na esfera mais ampla da cultura. Publicados respectivamente em 1899 e 1902, os referidos livros trouxeram à luz duas temáticas que marcam profundamente a era contemporânea - a educação e a religiosidade -, motivo pelo qual o seu estudo dá margem a inúmeras reflexões.

Nossa pesquisa, porém, limitou-se a tentar compreender as concepções educacionais jamesianas por intermédio de suas reflexões acerca da experiência religiosa, no intuito de contribuir com todos os que buscam melhores caminhos para a educação na atualidade. Mesmo nesse campo restrito, esta seção final não pretende esgotar todas as possibilidades abertas por James. O que ora apresentamos são algumas considerações a título de finalizar este trabalho acadêmico, esperando servir de inspiração para trabalhos futuros dedicados aos temas aqui abordados.

As formulações de James concebem o ser humano como um ser prático, opondose a teses que, na linhagem cartesiana, situam a razão pensante como essencial na definição de homem. São essas formulações que catalisam as reflexões do filósofo sobre o processo educativo, assumido como meio de formação do comportamento, descrevendo um processo que envolve as noções de paixão e hábito. É assim também que James entende a experiência religiosa, pela qual o indivíduo conhece a si mesmo e assume novas condutas. Os fenômenos da educação e da religiosidade, portanto, possuem traços comuns, tanto no modo como são caracterizados quanto nos fins a que conduzem o indivíduo.

Não encontramos em James uma visão teleológica que aponte para um ideal de comportamento e, consequentemente, para uma forma de educação capaz de preparar o indivíduo para a vida de maneira absoluta. $\mathrm{O}$ que se apresenta é a ideia de continuidade como qualificativo de um comportamento cujas bases advêm da adesão do filósofo à biológica evolucionária darwinista. O processo evolutivo é um perpétuo devir, situando

o indivíduo na constante tensão entre as condições postas pelo espaço circundante e as inclinações de sua individualidade, delineando o cenário de uma luta constante entre as limitações impostas pelo meio, cultural ou físico, e o esforço da pessoa para fazer 
escolhas, criar possibilidades inéditas. O ser humano prático é constituído na fronteira entre o que existe e o que pode ser.

A oposição de James à racionalidade cartesiana não implica ingressar na esfera da irracionalidade, mas a proposição de uma nova maneira de conceber a razão. A racionalidade jamesiana envolve a totalidade do ser em busca de adaptação, em busca de vida. O que define o homem é o empreendimento de ações concretas, é o compromisso com a invenção e com a disposição para adotar novas condutas, pois é assim que superamos os obstáculos externos e construímos nossa interioridade. Nesse processo, James enfatiza o valor das paixões, dos interesses, dos afetos, elementos que ocupam posição primeira em nossas escolhas. As paixões não são meras sensações que simplesmente se depositam em nós a partir do meio externo, mas algo tramado pela repetição constante das influências a que somos submetidos.

A proposta educacional jamesiana consiste em identificar e controlar as paixões que nos inclinam a maus hábitos, que vão de encontro a horizontes de progresso, nos impedindo de raciocinar e agir livremente e criativamente. $\mathrm{Na}$ formação do comportamento, James menciona a necessidade de modelos de conduta, certos modos de agir e raciocinar que podem operar como ferramentas para a constituição da identidade. Tais modelos não são necessariamente pessoas, podendo ser concepções filosóficas ou doutrinas religiosas; em suma, são elementos enraizados na dimensão cultural que atuam na constituição moral que se imprime nas relações humanas.

Compreender o que mobiliza uma pessoa, tanto no âmbito biológico quanto no da cultura, é a chave para a formação de comportamentos, sendo esta a função que se espera da instituição de ensino. Essa tarefa vai além da seleção de conteúdos e informações que visam aproximar os estudantes de tudo o que de mais importante foi produzido ao longo da história. Em James, o conhecimento científico aplicado à escola ganha novo significado, pois, naquele espaço dedicado ao ensino, o saber é instrumentalizado para servir ao controle das paixões, do que resultam novos modos de pensar e de agir moralmente.

É nesse contexto, em que se situam a escola como instituição e as relações ali estabelecidas entre professores e estudantes, que certo tipo de experiência - a que James dá o nome de religiosa - pode ser utilizada como meio para a criação de significados, para o reconhecimento da moralidade e para a articulação de conexões ativas com algo que transcende o imediato. James chama de divino esse elemento transcendente que atua na interioridade da pessoa. É o divino que, em cada um de nós, responde pela 
conjugação da passionalidade com a moralidade, do que resultam a deliberação e a disposição para agir.

A razão não existe para justificar as paixões, embora possa fazê-lo; a ação não é um simples meio para conectar as paixões com o mundo fenomênico; razão e paixões se conjugam para tornar o indivíduo aberto à vida, ao cultivo de uma vida mais ampla, mais comunicativa, mais compartilhada, no interior de um processo contínuo de aprendizagem que conduz ao reconhecimento do outro e, assim, à constituição da identidade pessoal. Esse processo pode se dar em qualquer instância da sociedade, mas, no que se refere à investigação aqui desenvolvida, pode ser atribuído como responsabilidade da escola.

As situações formais de ensino podem ser convertidas em laboratório para as vivências do aluno na cultura, de modo a despertar nele sensações e ideias nunca antes experimentadas. Ao abrir espaço para pensar essa nova forma de educação, James nos permite enxergar a experiência educacional, à semelhança da experiência religiosa, como um meio para quebrar sequenciamentos mecânicos, desestabilizar o que é dado como verdadeiro e abrir caminho para formas inéditas de perceber o mundo, sempre em conexão com o outro, cujas experiências nesse mesmo ambiente são decisivas para elaborar a nossa própria visão do real.

O trabalho com os sentimentos proposto por James diz respeito à ampliação de nossa riqueza interior, o que se consolida com a suspensão de nossas paixões, não com o propósito cético de suspender o juízo, mas com o intuito de identificar e analisar o que nos mobiliza passionalmente e intelectualmente. Só assim podemos alcançar o conhecimento de nós mesmos na direção de respeitar o outro, em conformidade com o que se espera em um ambiente democrático. Essa tarefa, que pode ser assumida pela escola, significa realçar em cada indivíduo o que, no vocabulário jamesiano, recebe o nome de sagrado. Em vez de isolar a vida mental do estudante no interior de uma redoma de matérias escolares e valores dogmáticos, trata-se de estimular a criação de estratégias de aproximação com os seus pares, no que podem ser úteis as atividades artísticas e outras variedades de ações comunicativas.

James abre espaço para pensarmos a escola como ambiente formador de indivíduos capazes de construir significados compartilhados, utilizando para isso o debate democrático em busca de consensos, a valorização da individualidade sem desprezo pelos fatores objetivos que circunscrevem a instituição de ensino. Nesse aspecto, James pode ser visto como um adepto - na verdade, um predecessor - das 
concepções que, no último capítulo deste trabalho, caracterizamos como responsáveis por questionar as tendências predominantes no cenário pedagógico atual.

James pode ser inscrito no rol de autores como Dewey, Quintiliano, Hansen, Crick e tantos outros cujas formulações inspiram uma pedagogia dedicada a construir formas mais inventivas de educar, conciliando a transmissão de saberes com a instituição de ações livres e independentes, tendo no horizonte um devir livre e responsável. As concepções filosóficas e educacionais de James podem ser vistas como vinculadas ao desejo por uma pedagogia radical que, inspirada na atuação dos sofistas, aproveite as energias dos alunos e as canalize para o cultivo de hábitos de crescimento individual dedicado ao acolhimento do outro, para a fé em um modo de vida compartilhado condizente com uma sociedade verdadeiramente democrática. 


\section{REFERÊNCIAS}

AGASSIZ, Louis; AGASSIZ, Elizabeth Cabot Cary. Viagem ao Brasil: 1865-1866. Tradução de Edgar Süssekind de Mendonça. Brasília: Senado Federal, 2000. http://www2.senado.leg.br/bdsf/item/id/1048 <acesso em 29/08/2016>.

BREDO, Eric. The darwinian center to the vision of William James. In: BREDO, Eric; GARRISON, Jim; PODESCHI, Ronald (Orgs.). William James \& education. New York: Teacher College, 2002. p. 1-26.

GARRISON, James. O pragmatismo como método de transcendência individual criativa e afetiva da humanidade. Tradução de Roberto Cavallari Filho. Educação e Cultura Contemporânea, Rio de Janeiro, n. 8, v. 4, jul./dez. 2008.

BREDO, Eric; GARRISON, Jim; PODESCHI, Ronald. Introduction. In: BREDO, Eric; GARRISON, Jim; PODESCHI, Ronald (Orgs.). William James \& education. New York: Teacher College, 2002. p. xi-xix.

BJORK, Daniel W. William James: the center of his vision. New York: Columbia University, 1988.

CHILDS, John Lawrence. Pragmatismo y educacion: su interpretación y crítica. Tradução de Josefina Ossorio e Aída Aisenson. Buenos Aires: Editorial Nova, 1959.

COLE, Douglas. The value of a person lies in his herzensbildung: Franz Boas' Baffin Island letter-diary, 1883-1884. In: STOCKING, George W. (Org.). Observers observed: history of anthopology, vol. 1. Wisconsin: University of Wisconsin, 1983. p. 13-52.

CRICK, Nathan. Compor a vontade de poder: John Dewey sobre a educação retórica para uma democracia radical. Educação e Cultura Contemporânea, Rio de Janeiro, n. 28, v. 12, p. 164-183, 2015.

CUNHA, Marcus Vinicius. Comunicação e arte, ou a arte da comunicação, em John Dewey. Revistas Brasileiras de Estudos Pedagógicos. Brasília, n. 213/214, v. 86, p. 920, maio/dez. 2005.

CUNHA, Marcus Vinicius. Experiência, poética e utopia na educação. In: PAGNI, Pedro Angelo; GELAMO, Rodrigo Pelloso (Orgs.). Experiência, educação $e$ contemporaneidade. Marília: Poiesis, 2010.

CUNHA, Marcus Vinicius. A atualidade de John Dewey para a educação: mais arte, não menos. Educação e Cultura Contemporânea, Rio de Janeiro, n. 28, v. 12, p. 67-83, 2015a. 
CUNHA, Marcus Vinicius. Arte, experiência e educação: o que a mensuração não pode mensurar. In: MORALES, Juan Mario Ramos; CASTAÑEDA, José Antonio Serrano; REYES, Blanca Flor Trujillo (Org.). Deliberar com John Dewey: ciencias sociales y educacíon. México: Universidad Pedagógica Nacional, 2015b.

DEWEY, John. Democracia e educação: introdução à filosofia da educação. Tradução de Godofredo Rangel e Anísio Teixeira. São Paulo: Nacional, 1959.

DURKHEIM, Émile. Pragmatismo e sociologia. Tradução de Aldo Lataiff. Florianópolis: UFSC, 2004.

FERREIRA, Mariana Tavares. Nota da tradução. In: JAMES, William. A psicologia e a arte de ensinar. Cognitio-Estudos, São Paulo, v. 7, n. 2, p. 191-196, jul./dez. 2010.

GARRISON, Jim. James's metaphysical pluralism, spirituality, and overcoming blindness to diversity in education. In: BREDO, Eric; GARRISON, Jim; PODESCHI, Ronald (Orgs.). William James \& education. New York: Teacher College, 2002. p. 2741.

HANSEN, David T. Uma poética do ensino. Educação em Revista, Marília, n. 6, p. 95$127,2005$.

HANSEN, David T. O conhecimento moral como um objetivo para a educação: John Dewey. Educação e Cultura Contemporânea, Rio de Janeiro, v. 4, n. 8, p. 23-33, jul./dez. 2007.

HICKMAN, Larry A. Evolutionary naturalism, logic, and lifelong learning: three keys to Dewey's philosophy of education. In: GARRISON, Jim (Org.). Reconstructing Democracy, recontextualizng Dewey: pragmatism and interactive constructivism intwenty-first century. Albany: University of New York, 2008. p. 119-135 JAMES, William. Talks to teachers on psychology: and to students on some life's ideals. New York: Henry Holt and Company, 1899. https://archive.org/details/talkstoteachers1 1jamegoog < acesso em 15/02/2015>.

JAMES, William. The varieties of religious experience: a study in human nature. New York: Longmans, Green, and Co, 1917. https://www.gutenberg.org/files/621/621pdf.pdf < acessado em 13/05/2017>.

JAMES, William. The principles of psychology. Chicago: Encyclopedia Britannica, 1952.

JAMES, William. As variedades da experiência religiosa: um estudo sobre a natureza humana. Tradução de Octavio Mendes Cajado. 10. edição. São Paulo: Cultrix, 1995. 
JAMES, William. A vontade de crer. Tradução de Cecília Camargo Bartalotti. São Paulo: Loyola, 2001.

JAMES, William. A psicologia e a arte de ensinar. Cognitio-Estudos, São Paulo, v. 7, n. 2, p. 191-196, jul./dez. 2010.

JOHNSON, Aostre. James's concept of mystical consciousness: implications for curriculum theory and practice. In: BREDO, Eric; GARRISON, Jim; PODESCHI, Ronald (Orgs.). William James \& education. New York: Teacher College, 2002. p. 151171.

MACHADO, Maria Helena P. T. (Org.). O Brasil no olhar de William James: cartas, diários e desenhos, 1865-1866. São Paulo: Edusp, 2010.

MASSCHELEIN, Jan; SIMONS, Marteen. Porque nossas crianças não são nossas crianças ou porque a escola não é um ambiente de aprendizagem. Revista SulAmericana de Filosofia e Educação, n. 23, p. 282-297, nov.2014-abr.2015.

MENAND, Louis. The metaphysical club: a story of ideas in America. New York: Farrar, Straus and Giroux, 2001.

MIEDEMA, Siebren. James's metaphysics of experience and religious education. In: BREDO, Eric; GARRISON, Jim; PODESCHI, Ronald (Orgs.). William James \& education. New York: Teacher College, 2002. p. 74-88.

MURPHY, John. Pragmatismo. Tradução de Jorge Costa. Porto: Asa, 1993.

NIEBUHR, Richard R. William James on religious experience. In: PUTNAM, Ruth Anna (Org.). The Cambridge Companion to William James. Cambridge: Cambridge University, 1998. p. 214-236

PAJARES, Frank. William James: our father who begat us. In: ZIMMERMAN, Barry J.; SCHUNK, Dale H. (Orgs.). Educational psychology: a century of contributions. London: Lawrence Erlbaum Associates, 2003. p. 41-64.

PHILLIPS, Denis C. From radical empiricism to radical constructivism, or William James meets Ernst von Glasersfeld. In: BREDO, Eric; GARRISON, Jim; PODESCHI, Ronald (Orgs.). William James \& education. New York: Teacher College, 2002. p. 115129.

PIMENTA, Rita. O que complementa uma poética do ensino? Uma retórica do ensino. Revista Brasileira de Estudos Pedagógicos, Brasília, n. 221, maio/ago., 2009.

PODESCHI, Ronald. Pluralism and professional practice: William James and our era. In: BREDO, Eric; GARRISON, Jim; PODESCHI, Ronald (Orgs.). William James \& education. New York: Teacher College, 2002. p. 58-73. 
POSNOCK, Ross. The influence of William James on American culture. In: PUTNAM, Ruth Anna (Org.). The Cambridge Companion to William James. Cambridge, New York, Melbourne: Cambridge University, 1998. p. 322-342.

PUTNAM, Hilary. Pragmatism: an open question. Cambridge: Blackwell, 1995.

PUTNAM, Hilary. A permanência de William James. Tradução de Clayton Foschiani. Cognitio-Estudos, São Paulo, v. 7, n. 2, p. 210-220, jul./dez. 2010.

PUTNAM, Ruth Anna. Some of life's ideals. In: PUTNAM, Ruth Anna (Org.). The Cambridge Companion to William James. Cambridge: Cambridge University, 1998. p. 210-220.

QUINTILIANO, Aimberê. Parrêsia e constituição do sujeito: democracia e educação. Childhood \&Philosophy, Rio de Janeiro, v. 8, n. 16, p. 379-404, jul./dez. 2012.

SHOOK, John. Os pioneiros do pragmatismo americano. Tradução Fábio Said. Rio de Janeiro: DP\&A, 2002.

VAN WESEP, Hendrikus Boeve. A estória da filosofia americana. Tradução de João Paulo Monteiro. Rio de Janeiro: Fundo da Cultura, 1966. 